\title{
THE ECOLOGY OF THE TAMAR ESTUARY VI. AN ACCOUNT OF THE MACROFAUNA OF THE INTERTIDAL MUDS
}

\author{
By G. M. Spooner, M.A. and H. B. Moore, Ph.D. \\ From the Plymouth Laboratory
}

(Text-figs. I-I2)

\begin{tabular}{|c|c|c|c|c|c|c|}
\hline \multicolumn{7}{|c|}{ CONTENTS } \\
\hline Introductior & & & . & . & . & $\begin{array}{l}\text { PAGE } \\
283\end{array}$ \\
\hline Material anc & ethods & & & 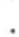 & & 285 \\
\hline Results of a & rsis of $t$ & $\operatorname{san}$ & & 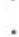 & & 288 \\
\hline List of speci & and the & list & ution & & & 300 \\
\hline Discussion & . & . & . & . & . & 323 \\
\hline Summary . & . & . & . & . & . & 328 \\
\hline References & . & . & . & . & . & 329 \\
\hline
\end{tabular}

\section{INTRODUCTION}

As pointed out in the Introduction to this series (Hartley \& Spooner, I938), a large part of the ground occupied by the estuaries of the Tamar and its confluent rivers, the Tavy and Lynher, consists of deposits of soft mud exposed at low water. A general account of the mud banks and flats, and their relation to tidal levels and position in the estuary, has already been given. Of the extensive intertidal zone (see 1938, Plate XVIII) by far the greater part provides a substratum of soft mud.

Owing to the extent of the intertidal muds, the fauna which they harbour must be regarded as one of the main elements of the fauna of the estuary as a whole. Supplying food for bottom-feeding fish ${ }^{\star}$ on the flood, and for various shore and wading birds on the ebb tide, its quality and quantity are likely to affect the numbers and distribution of the more conspicuous and economically important vertebrate population. Investigation of this particular element of the fauna was further prompted by the deficiency of information relating to it. While the main species frequenting this type of habitat in Britain are tolerably well known (though, as was discovered, not by any means completely), there is but little quantitative data of any sort relating to them. The difficulties presented to the investigator by the nature of the habitat are

* Lists of food organisms for the various estuarine fish are given by Hartley (1939) in this Fournal, pp. I-68. 
considerable, and probably explain why estuarine mud-dwelling faunas have been comparatively neglected.

This account deals essentially with the fauna permanently associated with the mud deposits, embracing species which are not dependent on the vegetation, deposits of weed, or other extraneous objects which may be lying on the surface of the mud. In the Tamar estuary the greater part of the surface of the muds is bare. In places, and at certain seasons, a thin coating of matted filamentous alga may be present, while locally there are growths of Zostera hornemanniana (see Tutin, 1936) and Z. nana. Zostera grows over large stretches of St John's Lake above the half-tide level, and thinly in restricted patches elsewhere. Ground supporting these limited types of natural vegetation is far from completely covered with the growths when the water rises over it, and the general facies of the burrowing fauna is unaltered. Surface-living forms are to some extent favoured by the additional surface and cover which the plants provide, but the species concerned are the same as those which are distributed over bare ground. It is another matter, however, where objects occur which provide close cover: for instance, clumps of brown algae, either loose or attached to scattered stones. These harbour a considerable population of Crustacea, etc., which evidently concentrate in them as the tide recedes. The cover provided by casually distributed stones, tin cans, etc., is similarly utilized. The fauna associated with such objects is here ignored, and will be dealt with on a future occasion.

Another group of species which fall outside the scope of this paper include forms such as mysids, shrimps, prawns, and gobies, which, though they sometimes occur in mud sievings, belong naturally to the free-swimming animal population. They occur only because they are liable to be stranded in shallow depressions as the tide recedes and to seek cover in the surface of the mud if the water drains away.

The microfauna of the muds, which includes small copepods, nematodes, etc., is being separately investigated by Mr P. R. Crimp as part of a more general survey of the microfauna of bottom deposits in the Plymouth area. Other types of littoral fauna in the Tamar also have been, or are being, studied. Population counts of the beach mollusc fauna at Torpoint, including some species dealt with here, are given in the second part of the work on the biology of Littorina littorea (Moore, I939).

In so far as the salinity gradient of the estuary is considered in this paper, reference is made to the recent investigations by Milne (1938). In assessing the effect of the salinity changes on the fauna of the bottom, especially those species which are able to retreat into burrows, it must be remembered that water retained in the mud is subject to less fluctuation than the supernatant river water, and is likely to be of an appreciably higher salinity (see Reid, I930; and Alexander et al., 1932).

Information relating to the tidal levels is given in the Introduction to this series (Hartley \& Spooner, I938, pp. 504-6). It will be noted that Ordnance 
Datum (O.D.), the zero standard to which levels are measured, is here nearly equivalent to the mid-tide level, being a little below mean sea-level and slightly above mean tide at Devonport. The mean range of the tide, measuring between $2.34 \mathrm{~m}$. (neaps) and $4.73 \mathrm{~m}$. (springs), is high compared with several districts in which attempts have been made to correlate fauna distribution with tidal level. This is a great advantage, since secondary fluctuations (resulting from varying winds, etc.) in the periods during which ground in the tidal zone is exposed are relatively small.

The primary object at the start of this work, after establishing what species were present, was to obtain some representative figures for their population density at different tidal levels and at different positions in the estuary. It proved possible to work a sufficient number of stations to give an indication expressed in quantitative terms of the way the various species are distributed in the tidal zone, as well as of their relative degree of penetration up-river.

\section{Material ANd Methods}

A series of localities was chosen as representative of the intertidal mud-flats as a whole, from St John's Lake, near the mouth of the estuary, to North Hooe at $18 \mathrm{~km}$. from the datum line at the mouth. At each locality a series of stations was selected to give as representative as possible a sampling of the transect down the entire shore from the salting edge to low water. In most places the upper levels of the tidal zone were occupied by saltings, but at St John's Lake and Thanckes Lake the traverse could be carried to high water. The sampling unit was a square of $0.25 \mathrm{sq}$. m. area. The ground, marked out with a wooden frame, was dug to a depth which varied with the nature of the ground, but was usually from I 5 to $30 \mathrm{~cm}$. The earliest samples worked, including most of those at St John's Lake and Clifton Flat, were not dug sufficiently deep to include quite all the burrowing fauna, but thereafter all samples were dug to a depth which appeared to include all animals. The ideal practice in work of this kind is to take a number of small samples at each station, and combine them for obtaining a fair sample of the area. In the present work the time and labour available for collecting, transporting the samples to the boat, and dealing with them subsequently, only permitted that at most a total of $\frac{1}{2}$ sq. $m$. of ground could be taken at each station of a traverse. But in dealing with soft muds there proved to be a limit to the size to which the unit sample could be reduced. If the area is much less than $\frac{1}{4} \mathrm{~m} .^{2}$ (the unit adopted), the difficulties of digging a clean edge are increased, and errors introduced by the caving-in of the sides of the excavation may become large. Consequently the best that could be managed was to take one or two samples of $\frac{1}{4}$ sq. m. surface area at each station. The mud was dug into a large sack, which was then tied up, labelled, and slid over the mud to the boat, where it was hoisted on board for sieving. If the sacking is new the risk of loss from the sample is negligible, and this method of 
transport of heavy masses of mud for a distance over soft mud-flats proved as practicable a method as could be devised.

The sieve used was made of perforated zinc with round holes $0.8 \mathrm{~mm}$. in diameter. A layer of the zinc formed the bottom of a wooden box a foot square in area and a foot deep. Sieving was found to be greatly facilitated when a window of fine gauze (of comparable mesh) had been fitted into the side of the sieve. When mud is being handled containing much vegetable matter, which easily clogs the bottom of the sieve, the larger particles tend to fall clear of the side window, thus allowing an exit for the muddy water; and though it also is found in practice to clog, the side window is much more easily kept clear than the bottom.

The mud from the sack was transferred in portions into a small bath standing inside a larger bath. In the former it was mixed by hand with water until it reached a soup-like consistency. Water was continually added to this bath and the mud suspension allowed to overflow into the larger bath, from which it drained through a plug over the side of the boat into the sieve. The fine washings collecting in the sieve were removed at intervals. Heavy objects, such as larger molluscs, stones, gravel, shells, etc., settled to the bottom of the baths, and were collected separately as "coarse" washings. This method of sieving has several advantages. The most important is that the more delicate animals are mostly undamaged, and do not get crushed to pieces as inevitably happens if the lumps of mud are broken in the sieve itself. Several people can work together round the bath, but even with only two a larger amount of mud can be handled in a given time than with any simpler method.

The samples of sieved material were washed clean in the laboratory, and spread out in flat dishes. The larger animals were picked out and the full number in the sample counted, while for the smaller sizes (typically the most numerous) it was necessary to have recourse to subsampling. Subsamples varied from one-sixth to one-third of the total matter, depending on the nature and bulk of the sieved material. These were worked through in detail. The coarse washings usually required a greater degree of subsampling than the fine washings.

An attempt was always made to reduce the additional error of estimation due to subsampling to a minimum. Every time as many animals as practicably possible were picked out of the whole sample, so that by far the greater bulk of animals, including all the larger, most of the medium-sized, and even many of the smallest individuals, were removed before the remainder was subsampled. For species still present in the subsamples the estimate of the total number, $N$, is simply obtained as follows:

$$
n_{1}+a n_{2}+b n_{3} \ldots=N \text {, }
$$

where $n_{1}$ is the number first removed from the whole sample, $n_{2}$ that removed from a portion of the sieving which had been divided to I/ $a$ of the total, $n_{3}$ that removed from another portion divided to $\mathrm{I} / b$, and so on. It is easily 
shown that the greater the value of $n_{1}$, that is to say the greater the number of individuals picked out of the whole sample, the smaller is the sampling error of $N$. Except for the very smallest sizes (e.g. Cardium spat), or abundant small species such as Hydrobia ulvae, the contribution made by $n_{1}$ was always the largest.

The catches were sorted within one or two days, before the animals had time to die and decay. There was thus no difficulty in distinguishing the living Hydrobia ulvae from the empty shells which were often present in great numbers, and which give great trouble in the sorting of preserved samples. The numbers of polychaetes, when the specimens were fragmented, were determined from the numbers of heads present.

The levels of the stations were determined at the time the samples were taken by means of a dumpy level, being referred to a fixed point on the shore or salting. At the same time the distance between the stations was measured either directly with a tape or by means of a range finder. The levels are not of any great accuracy on account of the difficulty of finding any firm foundation for the level. The levels of the fixed points on the saltings, to which all station levels were temporarily related, were themselves related to Ordnance Datum by a series of measurements taken in August 1937. At low tide the water in the estuary slopes down very considerably from the upper part of the estuary towards the mouth, but at high tide, when the whole width of the estuary is full of water, it may be assumed that the level is practically constant throughout. The measurements were made on a comparatively windless day, and in summer, so as to avoid any large flow of fresh water. During the low-water period a series of gauges were set up to record the highest point reached by the water at each locality on the next high tide. The gauges consisted of a length of about a metre of glass tubing coated inside with gelatine containing silver chromate, which changes colour in contact with sea water. The tube was lashed to a stake driven into the mud, and its lower end fitted with a short length of capillary tubing to damp out any wave action, the capillary tubing itself being protected from clogging with any floating mud by a piece of muslin tied over the end. The open top of the tube was protected from any possible rain by a small glass cap. The recorded heights of high water on each gauge were correlated with the fixed datum at each locality, and with Ordnance Datum through a measurement made at high water at a datum mark on the shore below the laboratory at Plymouth.

The greater part of the work was carried out during the summer months, when weather conditions and the temperature of the water were not too adverse. As a check, however, one traverse was worked on St John's Lake in February. The results, as will be seen, indicate no essential differences between the summer and winter population.

We wish to express our indebtedness to Messrs W. Searle and C. Haughton for their ready co-operation in the field work, and to several visitors to the 
laboratory who at one time or another helped in the collection of the material; to $\mathrm{Mr}$ P. H. T. Hartley who gave much valuable help at various times in dealing with the samples and in the surveying work; to Miss M. V. Lebour for assistance in naming the Mollusca, and to $\mathrm{Mr} \mathrm{D}$. P. Wilson for confirming the identification of polychaete species.

\section{Results of ANALysis of the SAMPLES}

The animal populations of all the stations worked, with estimates of the population density of each species present, are given in a series of Tables (I-VIII). The stations are grouped naturally, for the greater part, into traverses across the intertidal zone at different positions in the estuary. The actual positions of the traverses and the stations are shown on maps (Figs. I-6), which can be readily related to the plan of the estuary given in the Introduction to this Series (Hartley \& Spooner, 1938). In the Tables as much essential information as available is given for each station, e.g. tidal level, a general indication of the nature of the ground, and any noteworthy character of the solid material held in the mud. While the latter has not been studied in any detail, some note has been taken of the presence of excessive amounts of broken shells, stone fragments, vegetable fragments, leaf remains, etc.; and it may be pointed out that both the relative composition and total bulk of such solid matter held in the mud was found to vary greatly both in different localities, at different tidal levels, and even in adjacent positions at the same level.

The estimates of population density are expressed in number of individuals per square metre, since this has become an established standard in ecological literature. The use of this unit, as often happens, involves the somewhat unsatisfactory procedure of multiplying the original count or estimate by a figure ranging from $I_{3} \frac{1}{3}$ to 4 , and the approximate nature of the figures must therefore be strongly emphasized. In attempts to make comparisons it must be further remembered that the effects of marked patchiness of distribution could not be overcome by the sampling methods employed. The sort of differences that are shown between a number of stations worked on St John's Lake near the mid-tide level might have been expected on other traverses had more samples been taken at given levels. Full weight being given to these considerations, it is yet concluded that sufficient counts have been made to give, when taken in combination, a fairly clear picture of the order of population density attained by at least the more widely distributed species. As measures of the total macrofauna population, or for use in estimating the total bulk of animals, the total counts for each station are evidently good close approximations.

The areas investigated are dealt with in succession, progressing up-river. Twenty-four stations were worked on the broad flats of St John's Lake 

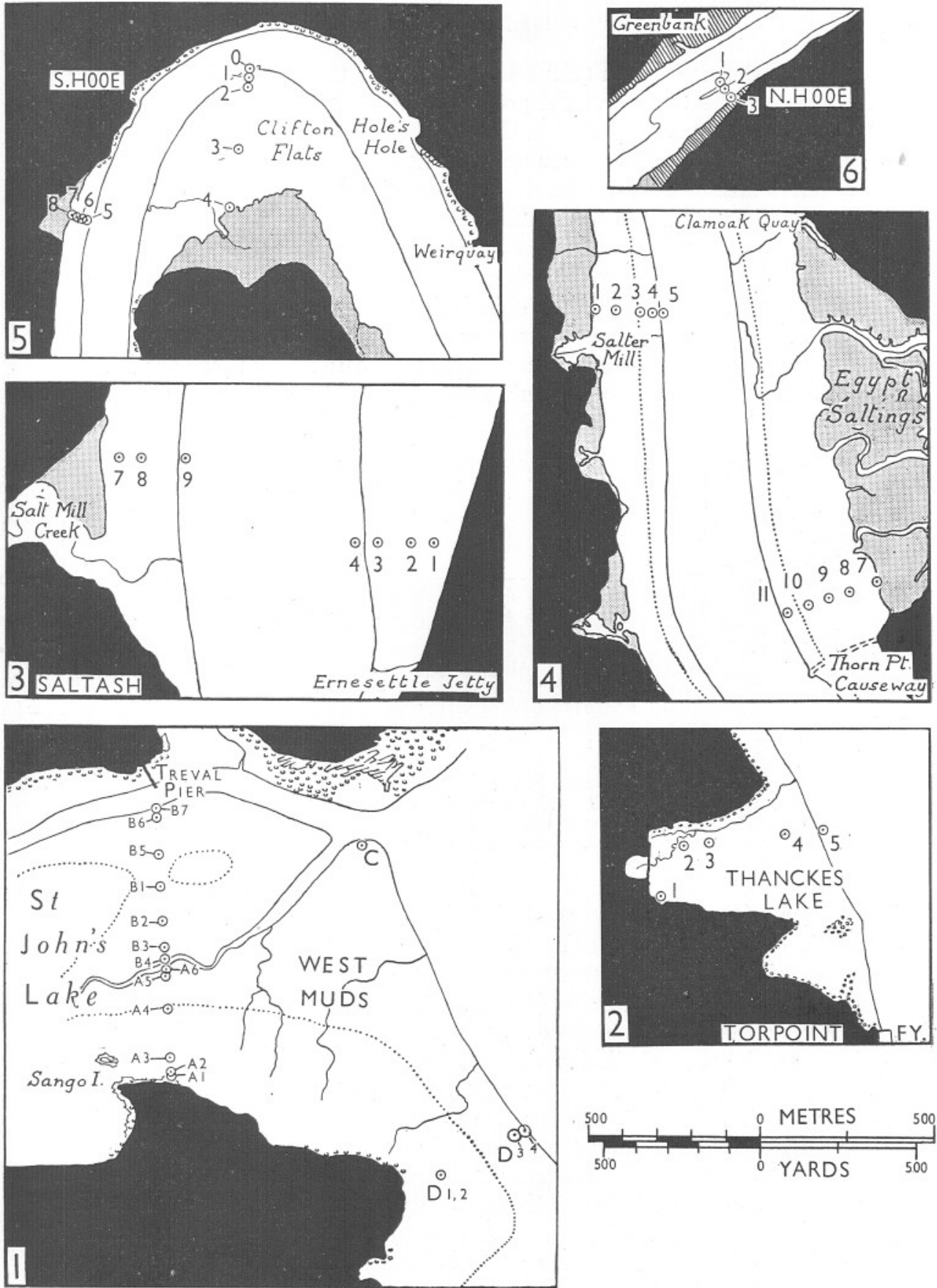

Figs. I-6. Maps showing the positions of stations at which sample population counts were made (Tables I-VIII). Land marked black; high grass saltings hatched; typical saltings marked in stipple; the permanent river and other channels marked by the M.L.W.o.T. line. The dotted line indicates approximate mid-tide level. I. St John's Lake area (Tables I-III). 2. Thanckes Lake (Table IV). 3. Flats above Saltash Bridge (Table V). 4. Flats between Cargreen and Weirquay (Table VI). 5. Clifton and South Hooe area (Table VII). 6. North Hooe area (Table VIII). 
(Fig. I): of these nineteen (Tables I and II), in thirteen positions, lie along a traverse passing from near Sango Island to the channel at Treval landingstage. A diagrammatic section of this traverse is given in Fig. 7, showing its drop to a narrow secondary channel, and rise to a wide "flat" lying between the levels $O$ and $-I \mathrm{~m}$. At levels between $+\mathrm{I} \cdot 0$ and $-0.25 \mathrm{~m}$. the surface of the ground is covered with a fairly continuous growth of Zostera hornemanniana. ${ }^{\star}$ The traverse crosses a moderately productive winkle ground. Some additional stations were worked on the "West Muds" adjoining the main river channel (Fig. I and Table III).

The total number of species listed is considerable, but some are not typical of soft mud habitats and others are irregular. Altogether there are included (i) true burrowing forms which are hidden below the surface when the tide

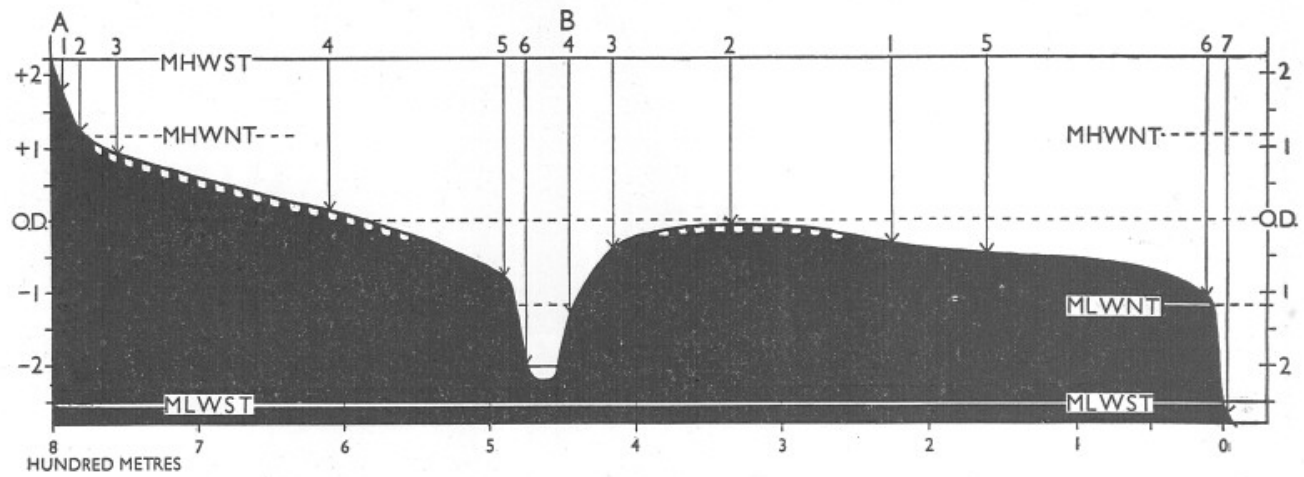

Fig. 7. Section of main traverse across St John's Lake (Fig. I and Tables I and II). Horizontal distances in metres from Treval channel. Vertical scale in metres from Ordnance Datum (O.D.). The positions of the stations (A I-6 and B I-7) are indicated by vertical lines, labelled along the top of the diagram. The broken white line indicates the extent of the Zostera growth.

has receded (Nereis, Nephthys, Heterocirrus, Ampharete, Mellina, Scoloplos, Corophium, Cardium, Macoma, Scrobicularia, Abra, etc.); (ii) forms which live freely exposed on the surface, though at times may retreat into the mud far enough to be hidden from view (Cereus, Hydrobia, Littorina spp. and Carcinus in part); and (iii) surface dwellers which make use of any available cover such as algal mats, shell deposits, vegetation debris, or growing Zostera (Sphaeroma, Gammarus, Carcinus, Idothea, and Littorina in part). The third group of animals is particularly liable to include species which are not strictly characteristic of soft muds: the occurrence of even the most regular species of the group is likely to be sporadic and dependent on local variations in the surface of the ground. Thus Sphaeroma only occurs in numbers where there is a thick deposit of old mollusc shells, and young Mytilus are entirely dependent on some solid object for attachment. The leaves of Zostera give an extra area of substratum to Littorina, Cereus, and Hydrobia, but the growth

* St John's Lake (Treval shore) is the type locality for this plant (Tutin, I936). 
Table I. St John's Lake, Main Traverse, May to August 1936. Numbers of animals per square metre

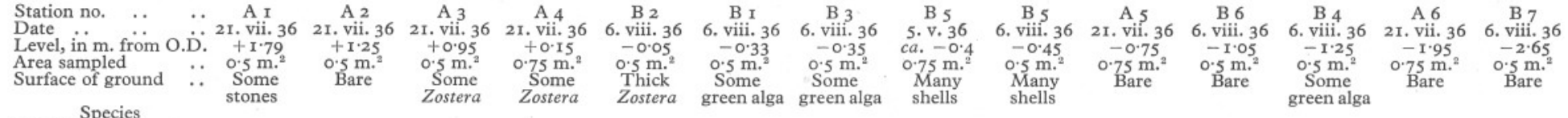
Species
Coklenterata

Cereus pedunculaturate

NeMERTINI

Nemertine spp.

POLYCHAETA

Leptonereis glauca

Scolecolepis fuliginosa

Ampharete grubei

Mellina palmata

Crustacka

Sphaeroma serratum

Gammarus spp. imm.

Melita palmata

INSECTA

Dipterous larvae

MollusCA

Hydrobia ulvae

Littorina littorea:

Over first yea:

L. saxatilis

Cardium edule:
Over $2 \mathrm{~cm}$.

$\mathrm{I}-2 \mathrm{~cm}$.

$0.5-1 \mathrm{~cm}$.
Below $0.5 \mathrm{~cm}$.

Macoma balthica.

Over $\mathrm{x} \cdot 2 \mathrm{~cm}$.

Below $\mathrm{r} \cdot 2 \mathrm{~cm}$.

Over $3 \mathrm{~cm}$.

$2-3 \mathrm{~cm}$.

$1.2-2 \mathrm{~cm}$.

Under $0.6 \mathrm{~cm}$.

Abra prismatica

A. nitida

Chiton sp.

..
.
..
$\because$
$\because$
10
$\ldots$
$\because$
$\because$
2

I0 $\quad . . \quad 3 \quad 32$

2140

$8200 \quad 14,160$

24,660

$32 \quad$..

.

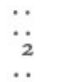

..

..

.. 16

$2 \dot{8}$

I0

$\left.\begin{array}{r}10 \\ 16 \\ 420\end{array}\right\} 26 \quad \begin{gathered}. . \\ 580\end{gathered}$

$\left.\left.\begin{array}{rl}21 \\ 39 \\ 360\end{array}\right\} 60 \quad \begin{array}{l}54 \\ 20 \\ 88\end{array}\right\} 74$

14203150

1008

58

. $\quad 24$

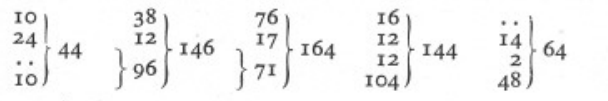

$\left.\left.\begin{array}{r}14 \\ 6 \\ 24\end{array}\right\} 4 \begin{array}{r}15 \\ \left\{\begin{array}{r}15 \\ 368\end{array}\right.\end{array}\right\} 3^{383}$

$\left.\left.\begin{array}{r}4 \\ 152\end{array}\right\} 156 \begin{array}{ll}346 \\ 134 \\ 10\end{array}\right\} 480$

$$
\text { . }
$$

.

Notes on nature of ground, and material retained by the sieve. All stations on soft mud. A I, on edge of the mud flat, much admixture of stony matter (shillet) and mollusc shells. A 2,

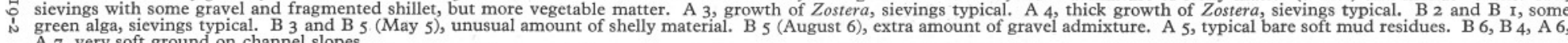

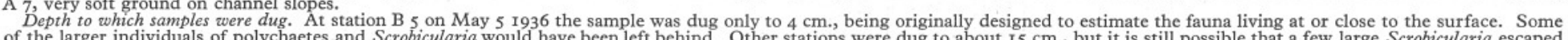

Note on fauna. Small Oligochaetes occurred in considerable numbers in some stations: these, however, are not included among the macrofauna. The absence of Nereis diversicolor Corophium volutator, and some other species which are listed in Tables II and III is noteworthy. The size-measurements of the groups into which the populations of bivalves are divided refer to lengths. The population of Littorina littorea is divided into year groups, of which the first is clearly separable from the rest. 


\section{Table II. St John's Lake, Main Traverse, February io 1937}

Numbers of animals per square metre

\begin{tabular}{|c|c|c|c|c|c|c|c|c|c|c|c|}
\hline \multirow{2}{*}{\multicolumn{3}{|c|}{ 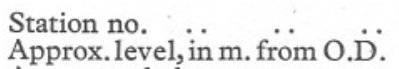 }} & \multicolumn{2}{|l|}{$\mathrm{B}_{2}$} & \multicolumn{2}{|l|}{ B I } & \multicolumn{2}{|l|}{$\mathrm{B}_{3}$} & \multicolumn{2}{|l|}{ B 5} & B 6 \\
\hline & & & \multirow{2}{*}{\multicolumn{2}{|c|}{$\begin{array}{l}-0.05 \\
0.5 \mathrm{~m}^{2}\end{array}$}} & \multirow{2}{*}{\multicolumn{2}{|c|}{$\begin{array}{l}-0.30 \\
0.5 \mathrm{~m} .^{2}\end{array}$}} & \multirow{2}{*}{\multicolumn{2}{|c|}{$\begin{array}{l}-0.35 \\
0.5 \mathrm{~m} .^{2}\end{array}$}} & \multirow{2}{*}{\multicolumn{2}{|c|}{$\begin{array}{l}-0.45 \\
0.5 \mathrm{~m}^{2}\end{array}$}} & $-I .05$ \\
\hline Area sampled & .. & .. & & & & & & & & & $0.5 \mathrm{~m} .^{2}$ \\
\hline $\begin{array}{r}\text { Surface of ground } \\
\text { Species }\end{array}$ & $\cdots$ & . & \multicolumn{2}{|c|}{ Bare } & \multirow{2}{*}{\multicolumn{2}{|c|}{ Zostera }} & \multicolumn{2}{|c|}{ Bare } & \multicolumn{2}{|l|}{ Bare } & Bare \\
\hline \multicolumn{11}{|l|}{ Coelenterata } & \\
\hline Cereus pedunculats & & & \multirow{2}{*}{\multicolumn{2}{|c|}{$\begin{array}{l}\ldots \\
\ldots\end{array}$}} & \multirow{2}{*}{\multicolumn{2}{|c|}{$\begin{array}{l}\text { IO } \\
\text { I2 }\end{array}$}} & \multicolumn{2}{|l|}{$\cdots$} & \multicolumn{2}{|l|}{. } & . \\
\hline \multicolumn{3}{|l|}{ Other Anemones* } & & & & & \multirow{2}{*}{\multicolumn{2}{|c|}{. }} & \multicolumn{2}{|l|}{. } & . \\
\hline Polychaeta & & & \multicolumn{2}{|l|}{$\cdots$} & \multicolumn{2}{|l|}{ I2 } & & & & & \\
\hline Nereis diversicolor & & & & & .. & & 8 & & 8 & & 2 \\
\hline Nephthys homberg. & & & I84 & & . & & $2 \mathrm{I} 2$ & & I76 & & I34 \\
\hline Heterocirrus zetlan & adicu. & & .. & & . & & $32+$ & & $\ldots$ & & . \\
\hline Ampharete grubei & & & $\cdots$ & & . & & . & & . & & . \\
\hline Mellina palmata & & & 6 & & $\cdots$ & & $\cdots$ & & $\cdots$ & & $\cdots$ \\
\hline Scoloplos armiger & & & 6 & & $\cdots$ & & 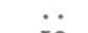 & & $\cdots$ & & . \\
\hline Phyllodoce macula & & & 4 & & $\cdots$ & & I0 & & $\cdots$ & & $\cdots$ \\
\hline Crustacea & & & & & & & & & & & \\
\hline Sphaeroma serratu & & & 6 & & . & & I2 & & $\cdots$ & & 2 \\
\hline Idotea viridis & & & 54 & & $\cdots$ & & Io & & $\cdots$ & & $\cdots$ \\
\hline Corophium volutat & & & $\because$ & & $\ddot{3}$ & & 2 & & $\ddot{i}$ & & $\cdots$ \\
\hline Carcinus maenas ju & uv. & & 2 & & 30 & & 2 & & & & $\cdots$ \\
\hline $\begin{array}{l}\text { Hydrobia ulvae } \\
\text { Littorina littorea: }\end{array}$ & & & I0,890 & & $8 \mathrm{I}_{3} \mathrm{O}$ & & 2260 & & - & & 30 \\
\hline $\begin{array}{l}\text { Over first year } \\
\text { First year }\end{array}$ & & & I6). & I6 & $\left.\begin{array}{r}68 \\
110\end{array}\right\}$ & I 78 & $\cdots$ & & $\begin{array}{c}8 \\
\ldots\end{array}$ & 8 & $\cdots$ \\
\hline L. saxatilis & & & 32 & & $\ldots$ & & $\cdots$ & & $\cdots$ & & $\cdots$ \\
\hline $\begin{array}{l}\text { Cingula sp. } \\
\text { Cardium edule: }\end{array}$ & & & 6 & & . & & . & & . & & . \\
\hline Over $2 \mathrm{~cm}$. & & & 4) & & 2) & & 4 & & 6 & & $2)$ \\
\hline $\mathrm{I}-2 \mathrm{~cm}$. & & & $\cdots$ & & 24 & & 4 & & $\cdots$ & IO & $\cdots$ \\
\hline $\begin{array}{l}0.5-1 \mathrm{~cm} . \\
\text { Under } 0.5 \mathrm{~cm} \text {. }\end{array}$ & & & $\ldots$ & 4 & $6\}$ & 32 & $\left.\begin{array}{r}4 \\
92\end{array}\right\}$ & 104 & $\cdots$ & 10 & $\begin{array}{l}\ldots \\
\ldots\end{array}$ \\
\hline Macoma balthica: & & & & & & & & & & & \\
\hline Over I cm. & & & 4). & I6 & I) & 2 & Io). & IO & $\because$. & 2 & $\cdots$. \\
\hline $\begin{array}{l}0.5-1 \mathrm{~cm} \text {. } \\
\text { Scrobicularia plan }\end{array}$ & & & I2) & 10 & I) & & $\ldots 1$ & & & & 4) \\
\hline Over $3 \mathrm{~cm}$. & & & $\cdots)$ & & 4) & & $\cdots)$ & & $\ldots)$ & & $\cdots)$ \\
\hline $2-3 \mathrm{~cm}$ & & & $\cdots$ & & $\cdots$ & & $\cdots$ & & $\cdots$ & & .. \\
\hline $\mathrm{I} \cdot 2-2 \mathrm{~cm}$ & & & $20\}$ & I38 & $\because$ & 6 & $\ddot{r}$ & 26 & 4 & 40 & $\cdots$ \\
\hline $\begin{array}{l}0.6-1 \cdot 2 \mathrm{~cm} \\
\text { Under } 0.6 \mathrm{~cm}\end{array}$ & & & $\begin{array}{l}32 \\
86\end{array}$ & & 2 & & $\begin{array}{l}\text { I2 } \\
\text { 14 }\end{array}$ & & $\begin{array}{l}\text { I4 } \\
22\end{array}$ & & 2 \\
\hline Abra nitida & & & .. & & .. & & . & & .. & & 4 \\
\hline Mytilus edulis (juv & & & $\ldots$ & & 24 & & $\ldots$ & & $\ldots$ & & $\ldots$ \\
\hline
\end{tabular}

Note. All stations on soft mud; B 2, sievings contained much vegetable detritus; B I, growth of Zostera and shelly matter in sievings well above average; B 3 , sievings typical; B 5, much vegetable detritus; B 6, on top edge of channel slope, much vegetable detritus. The samples were dug to a depth of at least $15 \mathrm{~cm}$. 


\section{Table III. St John's Lake, West Muds, Miscellaneous Samples \\ Numbers of animals per square metre}

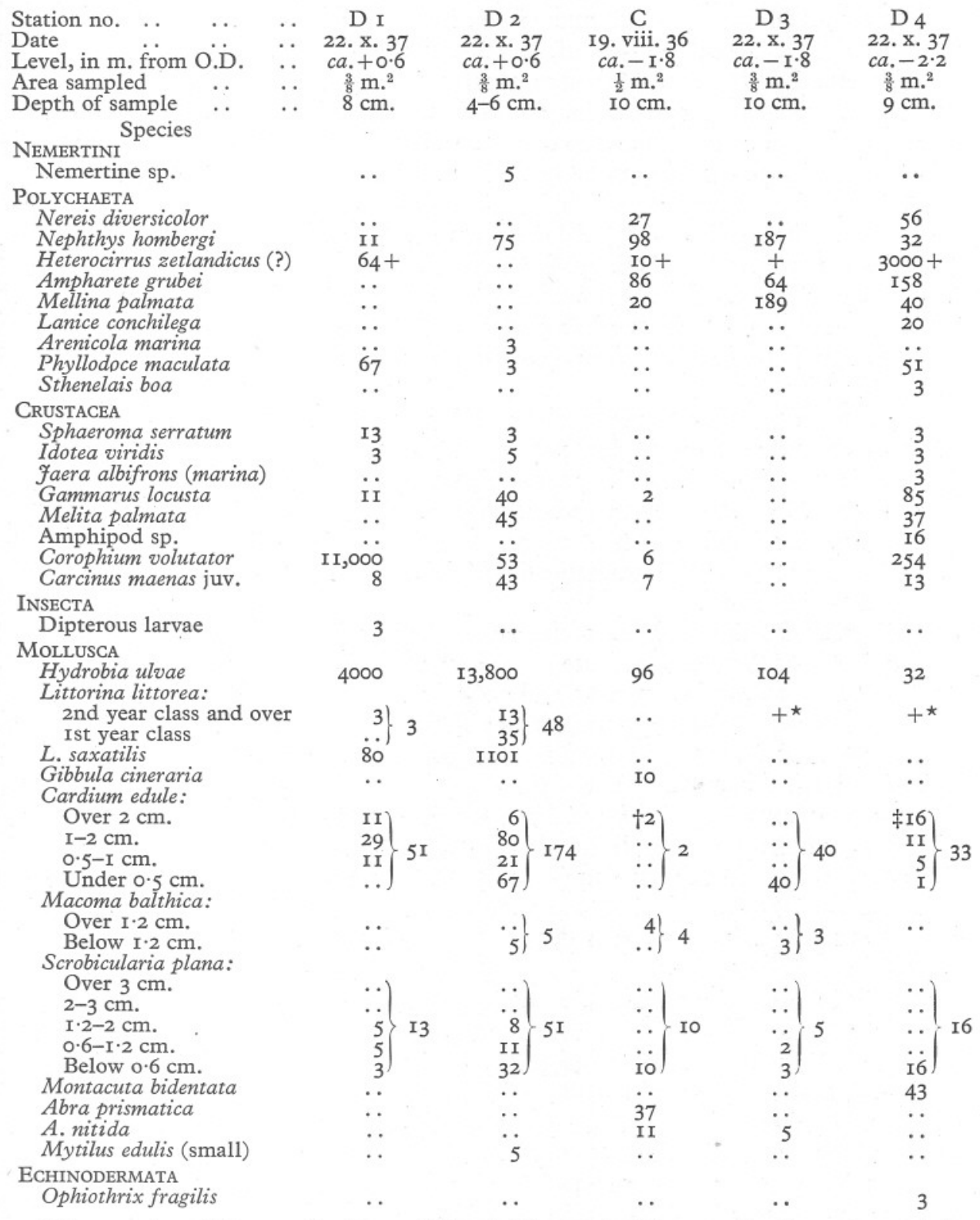

Notes on nature of the ground and material sieved. D I, patch of bare mud in Zostera zone; sievings typical. D 2, damp depression with thick growth of Zostera; sievings, apart from Zostera plants, typical. C, bare mud near main channel with surface ripples; sievings nearly all vegetable detritus. D 3 , black soft mud, sievings typical. D 4 , bare mud with heavy content of coarse shelly material; ground rather firm.

* Adult specimens present on ground with a density of $\mathrm{I}$ or 2 per $\mathrm{m}^{2}$

$\dagger$ Large specimens occurred freely on this ground. A number were hand-collected close by.

$\ddagger$ A high density of large-sized specimens. 
on St John's Lake is not sufficiently dense to bring in a new population of animals which concentrate in thick cover. It may be further noted that though Littorina littorea is often distributed in the open, concentrations are liable to occur round solid objects, clumps of weed, or where other cover exists: their distribution, as actually observed, is liable to be sporadic.

The true burrowers are of more regular occurrence over the area investigated, and it is among them that the effects of tidal level can best be tested. They include, however, a few irregular species, such as Arenicola marina and Lanice conchilega, which appear to find the substratum generally unsuitable, and Corophium volutator, which is probably exceptionally sensitive to disturbance of the ground by tidal currents (see p. 327). The most regularly distributed worms are Nephthys hombergi, from about mid-tide level downwards (see p. 304), and Ampharete grubei, also below mid-tide (see p. 307). Among molluscs, Cardium edule (see p. 317), Macoma balthica (see p. 322), and young Scrobicularia plana (see p. 3I8) occur in nearly every station worked.

Within the zone it occupies perhaps the most uniformly distributed species and most independent of the nature of the ground is the surface-living Hydrobia ulvae (see p. 3II). As readily seen by inspection of the ground, this mollusc is extremely abundant over many acres of mud-flat with its maximum density between $+0.5 \mathrm{~m}$. and just below O.D. The density distribution shown diagrammatically in Fig. II shows a clear zoning in relation to tidal level.

The salinities to which the main part of St John's Lake flats are exposed, excluding only the steeper slopes on the edges of the channels, may be taken as normally ranging between 35 and $30 \%$ in winter and almost marine conditions in drier periods of summer (see Milne, 1938). That there is definite estuarine influence is evident from the occurrence of Scrobicularia plana, Nereis diversicolor, and Idotea viridis.

A comparison of Tables I and II shows that there is little reduction of the fauna in winter. The polychaete Ampharete grubei is the only annual species which dies down in the autumn (see p. 307). The numbers of Hydrobia ulvae are significantly smaller, but the zone of maximum abundance may have been missed or not quite reached.

Table IV gives the results of a single traverse on Thanckes Lake, $3.4 \mathrm{~km}$. from the river mouth (Fig. 2). The paucity of species here as compared with St John's Lake is mainly due to the lack of variety in the types of ground sampled, and to the small number of the samples. There are however some other indications of an increase in estuarine conditions: namely a decrease in numbers of Cardium and Hydrobia, with the appearance of Nereis diversicolor in fair quantity above the half-tide level. Excepting the slope at the edge of the river channel, the salinities to which this stretch of mud is exposed are estimated as only slightly below those affecting St John's Lake. 
Two traverses were worked, one each side of the river, a little above Saltash Bridge (Fig. 3 and Table V). On the Cornwall shore, at the level of Salt Mill ( $7.8 \mathrm{~km}$. from the river mouth), the high water zone is occupied by an expanse of saltings, which gives place to bare mud at $\mathrm{I} \cdot 0 \mathrm{~m}$. above O.D. The Devon shore is here a stone railway embankment which artificially limits

\section{Table IV. Thanckes Lake Traverse, August 8 I937}

Numbers of animals per square metre

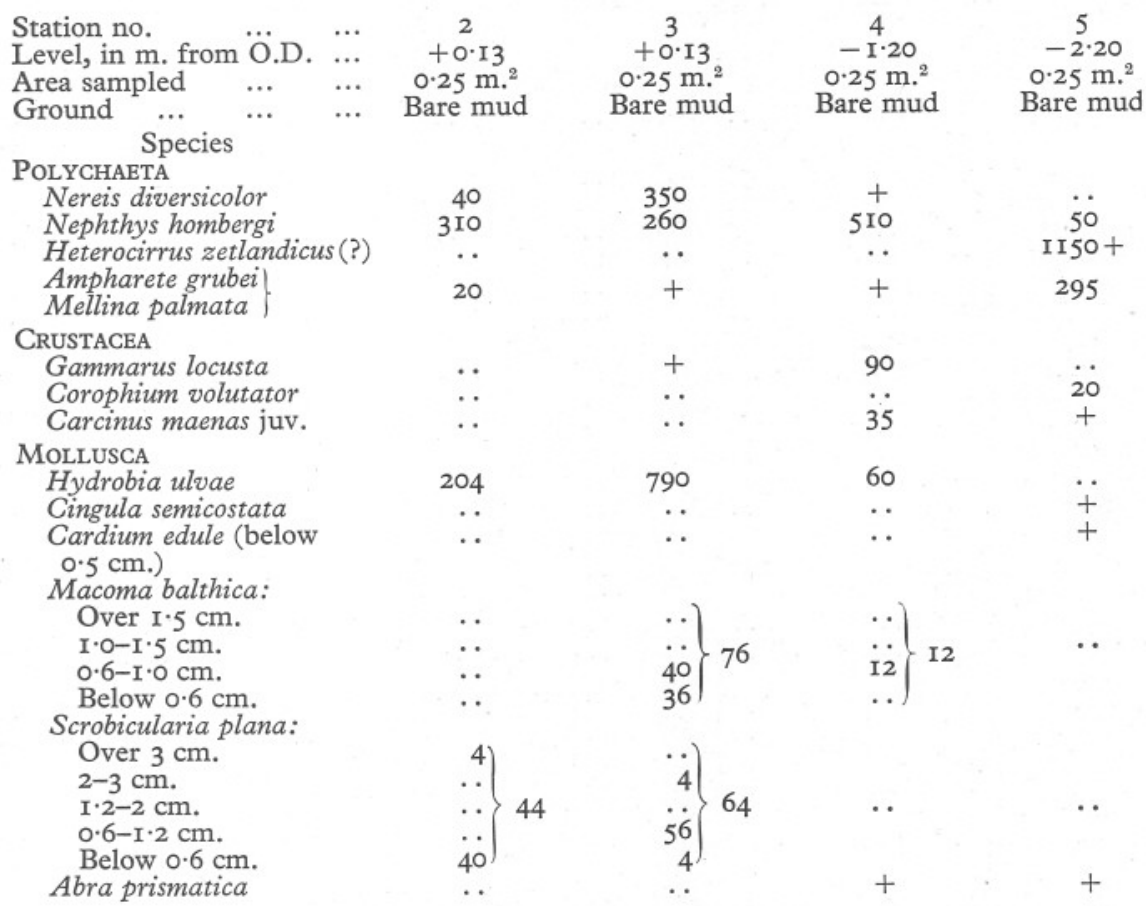

Note. Station I, at $+0.78 \mathrm{~m}$., on gravelly mud, yielded no fauna. In this table a bare + indicates that one specimen only was found in the sample.

the mud flat at a level just below O.D. The seven stations worked appeared well representative of the area, and the reduction in the number of species as compared with St John's Lake is certainly significant. Those which do not range up the estuary to this level include Ampharete, Scoloplos, and some other polychaetes; Chiton spp., Abra spp.; and Cereus pedunculatus. Of brackishwater species, Nereis diversicolor and Scrobicularia plana are well established, while Cyathura carinata and Gammarus zaddachi make their first appearance. A picture of the salinities prevailing in this locality has been given by Milne (I938), who studied the daily variation in detail on May 24 and June 31937. On the first date the salinity to which the low-water stations were exposed 


\section{Table V. Traverses above Saltash Bridge, May I3 1937}

\section{Numbers of animals per square metre}

Salt Mill, Cornwall Shore

\begin{tabular}{lcccc}
\cline { 3 - 4 } Station no. ... & $\ldots$ & $\mathrm{S} 7$ & $\mathrm{~S} 8$ & $\mathrm{~S} \mathrm{9}$ \\
Level, in m. from & $0 . \mathrm{D}$. & +0.96 & +0.26 & -2.25 \\
Area sampled ... & $\ldots$ & $0.5 \mathrm{~m}^{2}$ & $0.25 \mathrm{~m} .^{2}$ & $0.25 \mathrm{~m}^{2}$ \\
Surface of ground & $\ldots$ & Bare & Bare & Bare
\end{tabular}

\section{Species}

\section{Nemertini}

Nemertine sp.

Polychaeta

Nereis diversicolor

Nephthys hombergi

Mellina palmata

Lanice conchilega

Arenicola marina

Heteromastus filiformis

CRUSTACEA

Cyathura carinata

Sphaeroma serratum

Melita palmata

Corophium volutator

Gammarus zaddachi imm.

Carcinus maenas juv.

Mollusca

Hydrobia ulvae

Littorina littorea:

Above Ist year

Ist year

Cardium edule:

Over $2 \mathrm{~cm}$.

$\mathrm{I}-2 \mathrm{~cm}$.

$0.5-1 \mathrm{~cm}$.

Below 0.5

Scrobicularia plana:

Over $3 \mathrm{~cm}$.

$2-3 \mathrm{~cm}$.<smiles>c1c#cc#cc#1</smiles>

$0.6-\mathrm{I} \cdot 2 \mathrm{~cm}$.

Below $0.6 \mathrm{~cm}$

Mytilus edulis

INSECTA

Dipterous larvae
I090

2

$\begin{array}{rr}90 & 56 \\ 6 & 132 \\ \cdots & 4 \\ \cdots & \cdots \\ \cdots & \cdots\end{array}$

380

..

$\cdots$

.

2

I70

$\cdots$

..

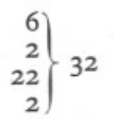

$\cdots$

$\cdots$

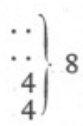

$\left.\begin{array}{c}4 \\ 36\end{array}\right\} 40$

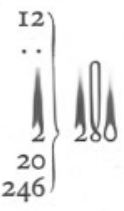

$\left.\begin{array}{r}\cdots \\ 4 \\ 12 \\ \cdots\end{array}\right\} 16$

40
Ernesettle Flats, Devon Shore

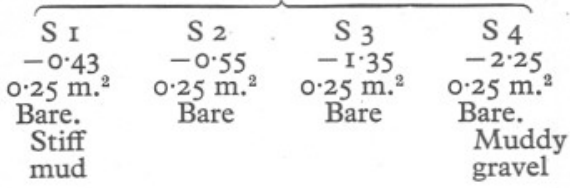

$\begin{array}{cr}\cdots & \\ 770 & \\ 40+ & 26 \\ \cdots & \\ \cdots & \\ 30 & + \\ 40 & \\ 4 & . \\ \cdots & \\ \cdots & \\ \cdots & \\ \cdots & \end{array}$

264
$\cdots$
$\cdots$
$\cdots$

$\ddot{2} \dot{8}$

I2*

96

I6

4

..

$\cdots$

..

.

$\cdots$

*

604

$+\$\}+$

4. 4

4. 4

$+\infty$

$\left.\begin{array}{l}\cdots \\ \cdots \\ 9\end{array}\right\} 9$

$\left.\begin{array}{l}\cdots \\ 4 \\ \cdots\end{array}\right\}^{4}$

$\left.\begin{array}{r}\cdots \\ 4 \\ \cdots\end{array}\right\} 4$

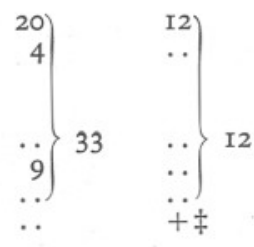

Note. All stations on mud, of varying softness, except $\mathrm{S}_{4} . \mathrm{S}_{7}$, sievings contained much shelly material, especially quantities of old shells of Hydrobia ulvae. S 8, also much shell content. S 9, very soft mud on channel slope; sievings contain stone fragments. S I, stiff mud, with high content of vegetable detritus. $\mathrm{S}_{2}$, rather soft mud, with high coarse shelly material content. $\mathrm{S}_{3}$, soft mud, typical sievings. $\mathrm{S}_{4}$, muddy gravel at low water springs; sievings contain unusual quantity of stone and shell fragments.

* Very large specimens.

† Very young individuals only.

\# Noted present on ground, but none in sample.

$\S$ Present on ground, about I per $\mathrm{m}^{2}$ At S 4 clustered locally. 
was as low as $17 \%$, and may be expected to fall to about $10 \%$ in the winter. The highest intertidal salinity on June 3 was $32 \%$. Milne (I938, Fig. 3) further gives high- and low-water salinities at Saltash from October 1936 to June I937. There is a marked seasonal variation: high-water value can be as low as $14 \%$ in winter and as high as $33 \%$ in autumn, and low-water values range from $32 \%$ to $8 \%$. To sum up, it can be said that the flats above Saltash Bridge, while subjected to wide daily and seasonal fluctuations in salinity, are never covered by "fresh" water below I $\% 0$, and, though during dry spells the water may regularly rise above $30 \%$, are never under the influence of full salinity sea water.

The next series of stations, worked on the flats between Cargreen and Weirquay (Fig. 4 and Table VI), show a still further depletion of marine species. Apart from the small Heteromastus, polychaetes are now represented by two species only, Nereis diversicolor and Nephthys hombergi, the latter in small numbers only and nearing the limits of its range, the former attaining a marked dominance over other worms. Among Crustacea, juvenile Carcinus maenas still occur, but Gammarus zaddachi and Sphaeroma rugicauda almost completely replace Gammarus locusta and Sphaeroma serratum, ${ }^{\star}$ while Cyathura carinata becomes a dominant species. Four species of Mollusca persist, Scrobicularia attaining dominance, but Cardium and Hydrobia occurring in greatly diminished numbers even on the most suitable ground. The upper limit of the three species of Littorina has been passed at Cargreen. It will be noted that the density of Nereis and Scrobicularia is sufficient to maintain the numbers of the total worm and bivalve population and counteracts the reduction or disappearance of other species. Extensive saltings, bordered for most of their length by an abrupt salting cliff, fringe this part of the river. The Nereis and Scrobicularia population extend through the salting creeks, and Nereis and Corophium volutator settle in salting pools. Hydrobia ulvae is much more plentiful in the saltings than on the mud flats. Salinities in this region are considerably lower than at Saltash. Near low water in wet periods in winter the channel may run almost fresh at the surface, while the highest summer salinity is not likely to exceed $27 \%$.

The flats off Clifton and South Hooe (Fig. 5 and Table VII) show a still further reduction in species. The upper limit of Cardium edule has been passed, and Hydrobia ulvae has declined still further. Nereis diversicolor is the only polychaete, but attains a high population density. The highest salinity to which the flats may be subjected, though by far the greater part of their surface rises above the half-tide line, is not likely to exceed $25 \%$. Finally, off North Hooe (Fig. 6 and Table VIII), the fauna is virtually restricted to Nereis and Scrobicularia. While the latter has started to decrease, the density of Nereis at the top of the mud bank was the highest obtained at any station worked. The

* Additional data relating to these species is being published in another contribution. 


\section{Table Vi. Traverses on Flats between Cargreen and Weirquay}

\section{Numbers of animals per square metre}

Salter Mill, Cornwall Shore,

I2.3 km. from mouth, July 22 I937

\begin{tabular}{l} 
Station no. ... \\
Level, in m. from O.D. \\
Area sampled .. \\
\multicolumn{1}{c}{ Species }
\end{tabular}

\section{Polychaeta}

Nereis diversicolor
Nephthys hombergi
Heteromastus filiformis $\ddagger$

\section{CRUSTACEA}

Cyathura carinata

Gammarus zaddachi

Carcinus maenas juv.

MollusCa

Hydrobia ulvae

Macoma balthica:

Over I. $5 \mathrm{~cm}$

$\mathrm{I} \cdot \mathrm{O}-\mathrm{I} \cdot 5 \mathrm{~cm}$.

$0.6-1 \cdot 0 \mathrm{~cm}$.

Below $0.5 \mathrm{~cm}$.

Cardium edule:

Over I cm.

$0.5-1 \mathrm{~cm}$.

$0.5 \mathrm{~cm}$.

Scrobicularia plana:

Over $3 \mathrm{~cm}$.

$2-3 \mathrm{~cm}$.

$\mathrm{I} \cdot 2-2 \mathrm{~cm}$.

$0.6-\mathrm{I} \cdot 2 \mathrm{~cm}$.

Below $0.6 \mathrm{~cm}$.

$610 \quad 180$

$\left.\begin{array}{r}4 \\ 28 \\ 4 \\ \ldots\end{array}\right\} 36$

$\left.\begin{array}{r}4 \\ 16 \\ 12\end{array}\right\} 32$

$\left.\begin{array}{r}\cdots \\ 4 \\ 4\end{array}\right\} 8$

76

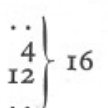

\begin{tabular}{l|l}
16 & 32 \\
I6
\end{tabular}

$\left.\begin{array}{r}4 \\ 32\end{array}\right\} 36$

$\left.\begin{array}{r}\cdots \\ \ldots\end{array}\right\} 4$

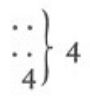

$\left.\left.\begin{array}{r}28 \\ 56 \\ 12 \\ 8\end{array}\right\} \begin{array}{ll}56 \\ \text { I04 }\end{array} \begin{array}{l}28 \\ 20 \\ 36 \\ 8\end{array}\right\}$ I48

$\left.\begin{array}{l}48 \\ 20 \\ 36 \\ 40 \\ 52\end{array}\right\} 196$

South End Egypt, Devon Shore, II $\cdot 2 \mathrm{~km}$. from mouth, May 26 I937

\begin{tabular}{|c|c|c|c|}
\hline $\begin{array}{c}\text { E I } \\
+0.48 \\
0.25 \mathrm{~m}^{2}\end{array}$ & $\begin{array}{c}\mathrm{E}_{2} \\
+0.33 \\
0.25 \mathrm{~m}^{2}\end{array}$ & $\begin{array}{c}\text { E } 3 \\
-0.12 \\
0.25 \mathrm{~m} .^{2}\end{array}$ & $\begin{array}{c}\mathrm{E} 4 \\
-0.96 \\
0.25 \mathrm{~m} .^{2}\end{array}$ \\
\hline
\end{tabular}

\section{E 7}

$\mathrm{E} 7$
+0.86

E 8

$+0.45$

E9
+0.39

$+0.39$

$0.25 \mathrm{~m}^{2}$

E Io

$+0.33$

$0.25 \mathrm{~m}^{2}$

E I I

$-\mathrm{I} \cdot 5 \mathrm{I}$

$0.5 \mathrm{~m}^{2}$

(1)

590
$\cdots$
$\cdots$

142
6
$90+$

130
8
$20+$

28

$\begin{array}{ccccc}64 & 282 & \text { 100 } & + & \cdots \\ 260^{\star} & \because & 30++ & \ldots & \text { I50+t }\end{array}$

..

$+$

470

I60

I2

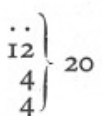

80

328

I4 2 i6

$\left.\begin{array}{c}\ldots \\ 20 \\ \ldots\end{array}\right\}^{20}$

$\left.\begin{array}{c}. . \\ 4 \\ 4\end{array}\right\} 8$

4
$\ldots$

$\left.\begin{array}{l}\cdots \\ \cdots \\ \dot{8}\end{array}\right\}$

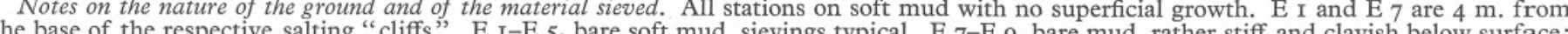
sievings with increasing content of vegetable detritus. E Io, softer mud; sievings with very little shelly material and large quantity of vegetable detritus. E II, very soft mud, rich in leaf deposit ("point stuff"); sievings with large quantity of dead leaves and twigs. All samples dug to at least $15 \mathrm{~cm}$. A bare plus sign indicates only one specimen in the sample.
* Mostly small immature.
$\ddagger$ A species too small to have been adequately sampled.
$\dagger$ All small immature; identity confirmed by rearing to maturity. 
Table VII. Traverses in Clifton and South Hooe Area, April 27 I937 Numbers of animals per square metre

Clifton Flats, Cornwall Shore, $14.2 \mathrm{~km}$. from mouth

Station no.

Level, in $\mathrm{m}$. from O. $\ddot{\mathrm{D}}$.

Area sampled .. Species

PolychaETA

Nereis diversicolor ${ }^{\star}$

Crustacea

Cyathura carinata

Corophium volutator

Gammarus zaddachi imm.

Carcinus maenas juv.

MOLlusCa

Hydrobia ulvae

Macoma balthica:

Above $\mathrm{I} \cdot 0 \mathrm{~cm}$.

Below I.O cm.

Scrobicularia plana: $\ddagger$

Over $3 \mathrm{~cm}$.

$2-3 \mathrm{~cm}$.

$\mathrm{I} \cdot 2-2 \mathrm{~cm}$.

$0.6-\mathrm{I} \cdot 2 \mathrm{~cm}$.

Below $0.6 \mathrm{~cm}$.

$\begin{array}{cccc}\overbrace{\mathrm{F} 4} & \mathrm{~F} 3_{3} & \mathrm{~F} 2_{2} & \mathrm{~F} \mathrm{I}_{1} \\ +0.73 & +0.58 & -0.07 & -0.79 \\ 0.25 \mathrm{~m}^{2} & 0.5 \mathrm{~m}^{2} & 0.5 \mathrm{~m}^{2} & 0.25 \mathrm{~m}^{2}\end{array}$

South Hooe, Devon Shore, $\mathrm{I} 4.8 \mathrm{~km}$. from mouth

One other station on the Clifton shore, $\mathrm{F}$ o, at $-\mathrm{I} .85 \mathrm{~m}$. level $\left(0.5 \mathrm{~m} .^{2}\right.$ area sampled) yielded no fauna.

Notes on the nature of the ground and material in sievings. All stations on bare mud. F 4, relatively firm ground, and sievings with little coarse material. F 3, relatively firm ground, sievings normal. F 2 , soft ground; considerable quantity of vegetable detritus. F I, soft mud with dense deposit of leaves and twigs ("point stuff"). F o, firm muddy sand at edge of channel, well scoured; sievings with large quantity of fine sand, and much "point stuff". F 6-8, soft mud, with extremely little solid matter. F 5, very soft mud, with extremely little solid matter.

* The figures for stations $\mathrm{F}_{4}, \mathrm{~F}_{3}$, and $\mathrm{F}_{2}$ should be a little higher, as the samples were dug only to Io $\mathrm{cm}$.: some of the largest Nereis were therefore missed.

† The great majority were small immature.
$\ddagger$ In stations F $_{2}-\mathrm{F}_{4}$ a few of the largest sizes may have been missed, owing to depth of sampling.

\section{Table VIII. Traverse at North Hooe, September 221937}

\section{Numbers of animals per square metre}

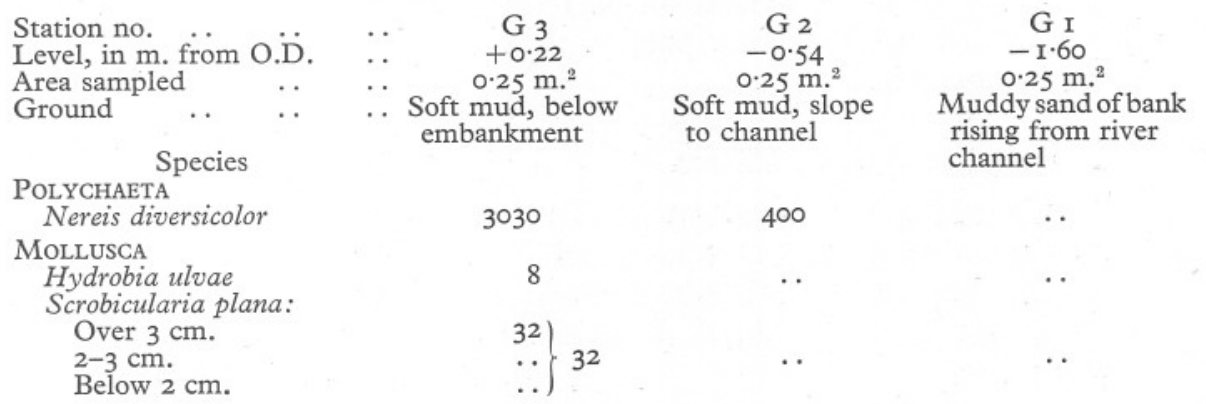


absence or scarcity of fauna in the lower levels of the tidal zone in the upper traverses is too striking to be disregarded. The cause is attributable to the scouring effects of the river channel, the evidence for which is discussed on p. 327 .

\section{List of SPECIES AND THEIR Distribution}

In summarizing the information on the various species encountered, it is usually possible to draw on additional data to those presented in the foregoing section, as general observations have been made in various parts of the estuary on occasions apart from those on which the quantitative samples were taken. Reference is also made (I) to certain other observations on neighbouring estuaries, and brackish-water habitats in Dorset; (2) to previously published records from the Tamar and other South-western estuaries; and (3) to published quantitative data referring to the species under consideration from whatever habitat. Species which have occurred casually, or which are more appropriately considered in connexion with habitats other than the intertidal mud-flats, are omitted. The names, unless otherwise indicated, follow the Plymouth Marine Fauna (193I).

\section{COELENTERATA}

Cereus pedunculatus (Pennant).

This anemone, which often occurs in great numbers in muddy estuaries as well as in a variety of other habitats, apparently finds conditions in the Tamar much less suitable than in the Salcombe estuary and Poole Harbour. On St John's Lake it occurs patchily, the highest density found being 58 per m. ${ }^{2}$ at a place where old mollusc shells were particularly numerous in the mud. It inhabits only the lower reaches of the estuary: Rat Island (Percival, I929) is the highest position recorded. At one station on soft mud in Poole Harbour there were 770 per $\mathrm{m}^{2}$

Phyllodoce maculata (L.).

\section{POLYCHAETA}

This species is one of several polychaetes which occur at the marine end of the estuary. It is more general on St John's Lake than the sample counts may suggest, though evidently patchy. Rat Island (Percival, 1929) appears to mark its upper limit.

Nereis diversicolor O. F. Müller.

This characteristic species of estuaries and brackish waters occurs abundantly in some part or other of all Devon estuaries, inhabiting intertidal flats, salting creeks, salting pools, and brackish ditches. At Weymouth, Dorset, it is plentiful in the mud of Radipole Lake and Lodmoor, in brackish lagoons of standing water. 
In all estuaries for which there are published fauna lists the general features of the distribution of $N$. diversicolor are the same. It is scarce or absent at the marine end, but becomes plentiful in the middle reaches of the estuary, where it is customarily reported as by far the most plentiful polychaete, and nearly, but not quite, reaches the upper limit of estuarine influence. It flourishes best in muds, and is partly replaced by other species in cleaner ground. In the Tees Survey Report (Alexander et al. 1935) some data of comparative abundance are given, based on counts of sample patches of ground through a $2 \mathrm{~mm}$. sieve, showing a steady increase up-river to a maximum abundance in the middle of the estuary, after which a steady decline follows. ${ }^{\star}$ Hitherto, however, it has not been clear to what extent this increase to a maximum in the middle reaches is simply the result of an increasingly favourable substratum, since in most estuaries the intertidal deposits are predominantly sandy at the sea end, and do not attain the consistency of soft mud for some distance from the mouth. This complication does not arise in the Tamar, and, as will be seen, the data secured seem to give a definite answer on this point.

In the Plymouth district the status of Nereis diversicolor as a marine species is doubtful. Though recorded occasionally from the Sound, it probably never establishes itself in permanent full salinity sea water. Passing into the Tamar Estuary, one finds it occurring patchily in the muds of St John's Lake adjoining the Hamoaze, apparently here confined to the lower tidal levels. Becoming more plentiful in Thanckes Lake, it steadily increases up-river, becoming an outstandingly dominant member of the fauna, and reaching its greatest density-over 3000 per $\mathrm{m}^{2}{ }^{2}$-at the highest station worked, North Hooe. Distribution diagrams are given in Fig. 8. Its upper limit in the river was not reached, but is given by Percival (I929) as half a mile above Calstock. Since in the Tamar a suitable substratum of soft mud is provided as low down as St John's Lake, it is clear that the progressive increase to the upper middle estuarine reaches is independent of substratum requirements.

As regards the optimum tidal level, Fig. 8 further demonstrates a clear preference for the upper half of the tidal zone, and an evident contrast in this respect with Nephthys hombergi (Fig. 9). Thamdrup (1935), investigating an area subject to comparatively high salinities and so near the seaward limit of this worm, records the species from all tidal levels over a wide stretch of muddy sand, the optimum (maximum density 320 per $\mathrm{m}^{2}{ }^{2}$ ) rather above (once at) mid-tide level. Wohlenberg (1937) found it well distributed on various types of ground in a bay at the north end of Sylt, but predominantly in the upper part of the tidal zone; several counts of $\mathrm{I} / 20 \mathrm{~m} .{ }^{2}$ samples indicate that the maximum density falls well short of 1000 per m. ${ }^{2}$ In the Isle of Man, generally on muddy sand, the worm can occur at all levels, but is generally

* The significance of these counts is impaired, as the authors of the Report emphasize, by the fact that variation with tidal level could not be taken into account, and successive samples may not have been strictly comparable: nevertheless a maximum somewhere in the middle reaches of the estuary is quite evident. 
NEREIS DIVERSICOLOR

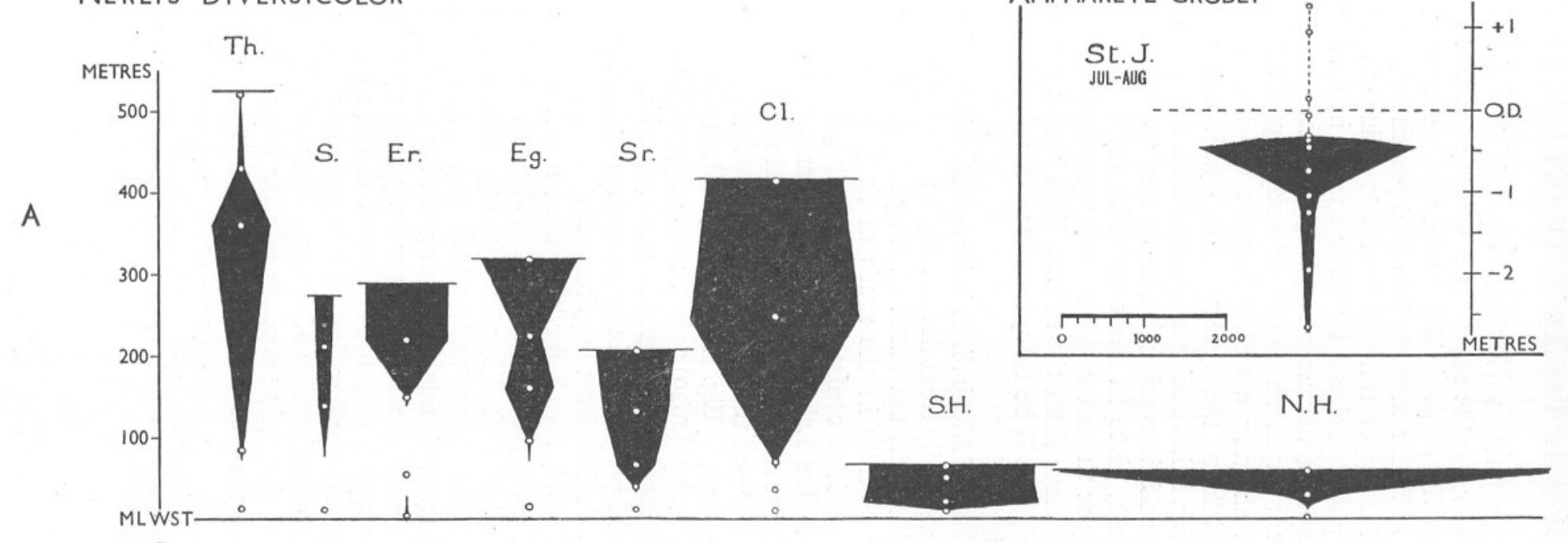

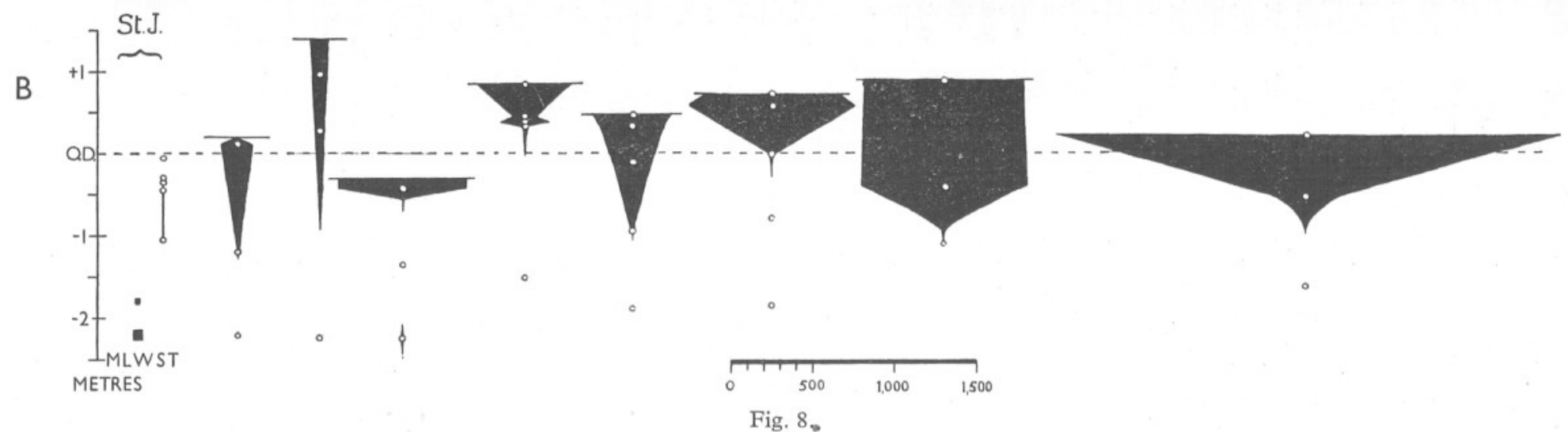


most abundant between mid-tide and high-water neaps (Moore, 1937b). Again, in Scotland Stephen (1929, 1930) records it from various more or less sandy localities as closely restricted to high-water mark, with a decided preference for places where the salinity is lowered by a stream. It is noteworthy that at the seaward end of its range in the Tamar, the worm has been found only in the lower half of the tidal zone, the region-perhaps significantly -in which the daily salinity fluctuations are greatest and in which the lowest salinities are encountered.

Such figures as have been published on population density fall well short of the higher values obtained in the middle reaches of the Tamar, but with one exception they all apply to habitats which clearly do not provide the optimum conditions for the species. Only in the Tees (Alexander et al. 1935) have counts been made in the middle reaches of an estuary. Here, however, a $2 \mathrm{~mm}$. sieve was employed and an allowance must be made for the smaller individuals which would have escaped collection. Judging from the size distribution of populations we have collected, we conclude that to multiply the Tees' figures by 3 is a generous allowance: the maximum (at section IX of the river) of 230 thus becomes 690 per m. ${ }^{2}$ In other sections of the river the densities were much less than this, and it is evident that the worm flourishes better in the Tamar than in the Tees. It only remains to mention the figures given by Nicol (1935) for another type of habitat, namely small salting pools. Averages of five counts of one square foot of ground for each of five pools give values ranging from 32 to 645 per m. ${ }^{2}$ In four other pools the estimates do not exceed the highest of the above counts. The typical densities of the more suitable intertidal habitats are therefore not reached. But in one pool on one occasion, presumably immediately after a spat-fall, 8890 young were counted in one square foot of mud, representing the extraordinary density of 95,700 per m. ${ }^{2}$

The fact that it attains its maximum density above mid-tide level shows that Nereis diversicolor suffers no disadvantage in habitats which are exposed to the air for longer periods than they are submerged. That exposure is not essential to the species, or conveys some possible advantage, is shown by its general occurrence in muds of brackish ditches and lagoons which are

Fig. 8. Nereis diversicolor: distribution diagrams for successive traverses, showing population density (numbers per $\mathrm{m}^{2}$ ) in relation (A) to position on the shore, and (B) to tidal level. The base-line of the top row (A) is mean low-water mark of spring tides, from which the distances of the stations and the upper boundary of the mud-flat are measured in metres. The bottom row (B) shows the same population counts plotted against tidal level, each diagram corresponding to the one above it. White dots or circles indicate positions of stations. A horizontal line across the top of a diagram marks the upper boundary of the mud-flat. The series, passing from left to right, represents the order of the traverses in an up-river direction. St.F. St John's Lake (Fig. I, Tables I-III); Th. Thanckes Lake (Fig. 2, Table IV); S. Salt Mill; Er. Ernesettle (Fig. 3, Table V); Eg. Egypt; Sr. Salter Mill (Fig. 4, Table VI); Cl. Clifton; S.H. South Hooe (Fig. 5, Table VII); N.H. North Hooe (Fig. 6, Table VIII). Inset: Ampharete grubei: distribution diagram for St John's Lake on main traverse in summer (Table I): numbers per $\mathrm{m}^{2}$ in relation to tidal level. 
permanently covered. It can be said that the worm is completely adapted to tolerate the necessity of remaining passively inside its burrow for long periods. With regard to its ability to withstand lowering of salinity, Ellis (I933) has shown that it is also well adapted in this respect, but seems to require a certain minimum of calcium salts in the water.

Nephthys hombergi Lamarck.

This is another widely spread burrowing polychaete, occurring in company with the above, but, as the data presented show (Fig. 9), with a decidedly different range. Occurring on the seashore, both intertidally and below low water, it penetrates some distance up estuaries in sands and muds. In the Tamar it is generally plentiful up to the flats at Saltash, from which point its numbers steadily decrease until it disappears altogether at about Weirquay. It occurred so regularly in samples in numbers ranging between 100 and 300 per $\mathrm{m}^{2}$ (once over 500 per $\mathrm{m}^{2}{ }^{2}$ ) that its normal density on average suitable ground appears to fall in this range. But at its zone of maximum abundance, encountered at Thanckes Lake (Table IV and Fig. 9), the greatest density obtained is far short of that reached higher up the river by Nereis diversicolor. Another contrast with the latter species is seen in its distribution within the tidal zone. Fig. 9 shows that this worm is regularly concentrated below the mid-tide line. In the estuary it is evidently better adapted than other animals associated with it to living in soft mud which is liable to constant disturbance by river currents. ${ }^{\star}$ In St John's Lake it was entirely absent from the upper stations of the main traverse, and its upper limit suspiciously abrupt: possibly it tends to avoid ground where there is a growth of Zostera, or where the surface is coated with a mat of filamentous green algae. The relative proportions of Nephthys and Nereis show a progressive change up-river, and might well prove useful as a biological indicator of the general conditions at different levels of an estuary.

The picture that may be drawn from the Tamar data of the distribution and abundance of these two widely distributed polychaetes, and of the contrasts which emerge between them, evidently represents a typical state of affairs. The penetration of the Nephthys into the lower reaches of estuaries is evidently general. In a locality such as Salcombe Estuary, in which no main river flows, and in which high salinities prevail well up into its narrow parts, this species may be expected to predominate. This was in fact found by Allen \& Todd (1900) who surveyed the fauna up to Garston Point, at which level the zone of predominance of Nereis diversicolor had still not been reached: the Nephthys was found to be about equally distributed from the mouth of the estuary to this point, and appeared to be one of, if not quite, the commonest polychaetes over the whole area investigated. In the Exe the same investigators (1902) found the Nephthys present generally in all types of ground, except the very

* The suspected reason is that it is comparatively active for a burrowing polychaete, and, unlike Nereis, does not occupy a permanent burrow. 


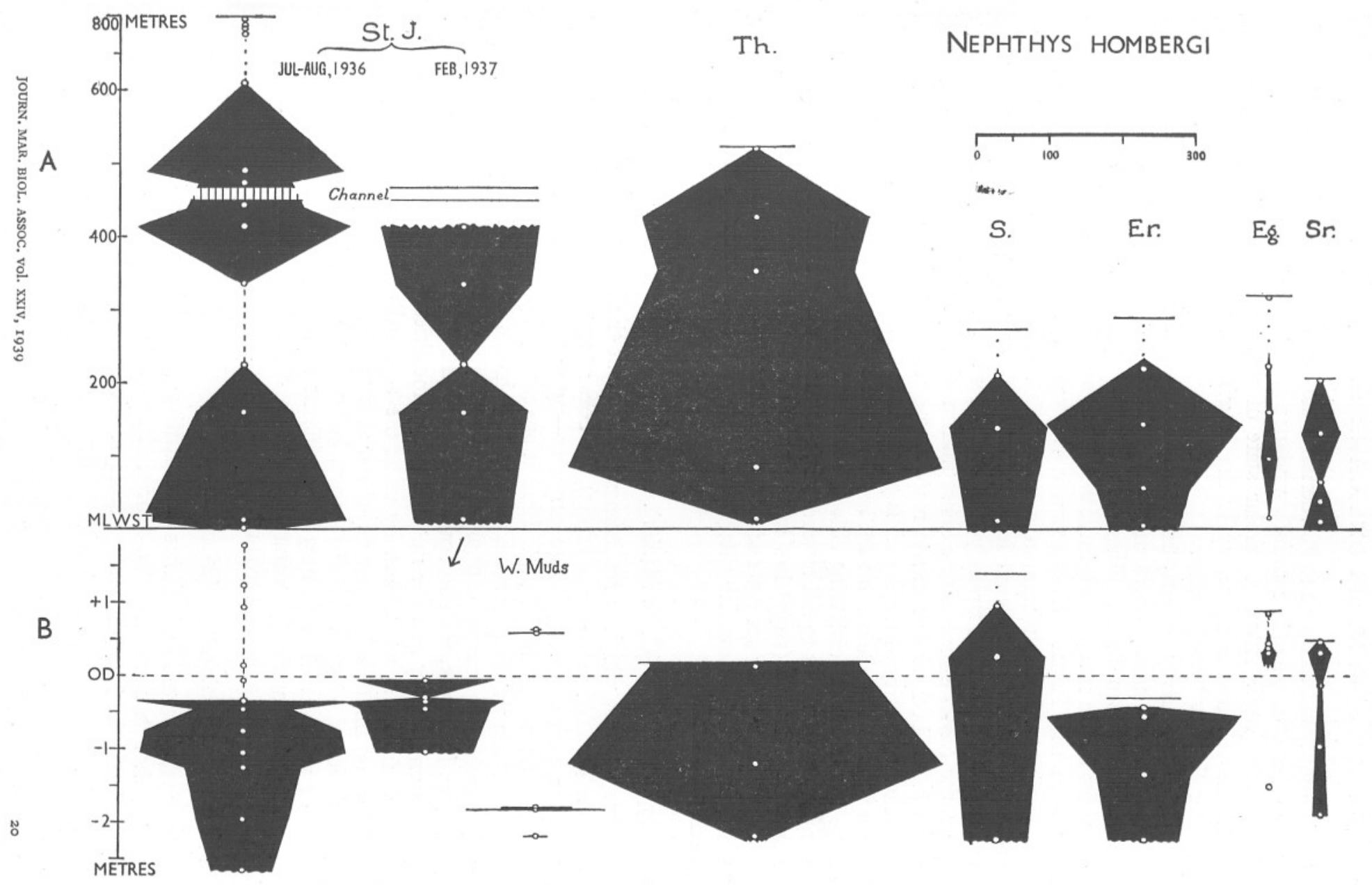

Fig. 9. Nephthys hombergi: distribution diagrams. Explanation as in Fig. 8. 
muddiest, from the mouth to Powderham, the Nereis being absent in the lower part of the estuary and becoming abundant towards Topsham. In the Mersey, Bassindale (1938) shows a similar state of affairs: the Nephthys does not penetrate the first narrows, while the Nereis is a dominant species in the "Inner Estuary" to Runcorn.

The Tees Survey Report, besides defining the complete range of the two species in that estuary, presents some quantitative data, to which reference has already been made. When the ranges, optimum zones, and relative densities of the two species, indicated by this data, are compared with those found in the Tamar, the agreement is striking. In both rivers Nephthys hombergi attains its maximum a little way from the seaward end of the estuary, as though it found its optimum in water of appreciably reduced salinity rather than in a purely marine environment. As it then declines upriver, the Nereis increases to a dense maximum in the middle reaches of the estuary. In both rivers, in the respective optimum zones of the species, the population density of the Nereis is greatly in excess of the other.

As regards its relation to tidal level, Thamdrup (1935) and Moore (1937b) have recorded it as occurring chiefly about low water or below, and Wohlenberg (1937) found it to fail towards high-water levels. In the Severn Estuary, however, Purchon (1937) has recently recorded it as plentiful in the zone between high-water springs and neaps at Portishead. It is variously recorded from dredgings below the tidal zone. No population counts have hitherto been published.

Scoloplos armiger (O. F. Müller).

This species, which is sometimes plentiful at the lower end of estuaries, e.g. the Tees (Alexander et al., I935), but does not penetrate any great distance up-river, occurred in moderate numbers-up to 152 per $\mathrm{m}^{2}{ }^{2}$-in some of the samples from St John's Lake. Here it appears to be restricted to the upper tidal levels in the Zostera zone, though polychaetes as a whole were scarce in this region. Thamdrup (1935) found it common on his main traverse at Skalling, Denmark, with an optimum well in the upper part of the tidal zone (maximum density 460 per m. ${ }^{2}$ ). In other localities it has been recorded at all tidal levels, as was found by us at the seaward end of Poole Harbour; with its optimum at varying positions, sometimes near low water (Stephen, 1929; Moore, 1937b). It also occurs below the level of tidal influence, in shallow water at least. It may be significant that St John's Lake is close to the limit of estuarine penetration, towards which limit a narrowing of the worm's vertical zone upwards may be expected.

Heterocirrus zetlandicus (MacIntosh) (?).

A small cirratulid which has been attributed to this species (e.g. Percival, 1929), though doubt may be expressed as to its true identity, occurred in several samples from the lower traverses. Owing to its small size and delicacy 
the species was imperfectly estimated. Only the larger individuals would have been retained by the sieve. It appears to occur in dense patches on suitable ground, and to reach a maximum in the region of low water. Neal Point appears to mark its upward limit of penetration.

Arenicola marina L.

The presence of the common lug worm is readily detected from its familiar castings, and the general scarcity of the worm in the intertidal zones of the Tamar Estuary can be confirmed by inspection of the ground. Patches of it have been noted here and there from West Muds to Thorn Point, and the lower end of the Tavy branch. The scarcity of this species may be due to the fact that it requires a considerable admixture of sand in its substratum. In the River Yealm, however, it colonizes a bank of extremely soft mud near Steer Point.

\section{Ampharete grubei Malmgren.}

This little-known tubicolous polychaete proved quite abundant on St John's Lake, in numbers up to 4000 per m. ${ }^{2}$ In the traverse stations (Table I) it occurred regularly from about mid-tide downwards, with a sharply defined maximum between this level and low-water neaps (Fig. 8, inset). On West Muds it occurred at all three lower stations, but not at the two higher (Table III). It was present in smaller numbers on Thanckes Lake, but nowhere higher up the river. Though a marine species, it is unrecorded from the sea around Plymouth. But it proved to be abundant intertidally in the mud at the seaward end of Poole Harbour, Dorset. In none of the published faunas of British estuaries (quoted under other species) is this worm recorded, but possibly sometimes it is overlooked among young stages of the allied Mellina palmata, or escapes capture owing to its somewhat small size. Wohlenberg (1937) records the species occurring intertidally at Sylt, and restricted to near low water.

The fact that it was completely absent in the winter (Table II), and that samples in the summer were composed of specimens of a uniform size which progressively increased from May to October, shows that, unlike other species dealt with here, Ampharete is an annual. It appears to have a limited breeding season in the autumn.

\section{Melinna palmata Grube}

This ampharetid, similar in habit and general appearance to the last, but attaining larger sizes, occurred in some stations in the lower part of the estuary. Up to Thanckes Lake it was always found in company with Ampharete, being most abundant at low water at the edge of West Muds, where I 89 per m. ${ }^{2}$ is the highest recorded density. But it was also present on the flats above Saltash, while Percival (1929) records it from the lower end of the Lynher up to Wivelscombe Lake: it evidently penetrates higher up the estuary than 
the other species. Unlike the latter, it is plentiful in Plymouth Sound (Plymouth Marine Fauna). Allen \& Todd (I900) record it, under the name of M. adriatica, as extremely abundant in the very finest mud in the Salcombe Estuary; but by contrast very scarce in the Exe (1902). No figures for population density have hitherto been published. The allied Mellina cristata was not encountered.

\section{Lanice conchilega (Pallas)}

In the lower Io $\mathrm{km}$. of the estuary this familiar terebellid occurs here and there on the fringes of the mud banks where the substratum near low water is noticeably of a gravelly consistency. Among the stations worked it occurred in two only, both at extreme low water, and where the ground was atypicalcontaining an excessive content of shelly or stony matter. The normal types of soft mud appear entirely unsuited to it.

\section{CRUSTACEA}

\section{Cyathura carinata (Kröyer).}

First recorded from the Plymouth district by Crawford (1936, 1937), this peculiar isopod proves to be a dominant species of the mud-flats in the middle reaches of the estuary. Like the amphipod Corophium volutator it inhabits burrows in the mud, an exceptional mode of life for an isopod. It ranges in the Tamar from Saltash at least to the region of Pentillie Quay. Percival (1929), recording it as Anthura gracilis, ${ }^{\star}$ found it on the mud-flats above St German's Bridge, while Crawford gives additional localities in Sconner Creek and the upper end of the Tavy estuary.

Fig. Io shows the regular occurrence of the species in the traverses from Salt Mill to South Hooe, where the dwindling numbers perhaps indicate that the upper limit is being approached. All traverses are consistent in showing a marked concentration above mid-tide level. The maximum densities from Salt Mill to Clifton Flat were respectively 378, 282, 304, and 288 per $\mathrm{m}^{2}{ }^{2}$-very consistent values which may with some confidence be taken to represent the order of maximum density reached in the Tamar in the optimum part of its range. The species was also found in the mud of Poole Harbour, where two stations yielded 200 and 34 per m. ${ }^{2}$ respectively.

\section{Sphaeroma serratum (Fab.).}

The species of Sphaeroma only barely qualify for inclusion in the mud fauna, as the main habitat of these partly cryptic and partly free-swimming isopods comprises the cover provided by clumps of weed, stones, and various casual extraneous objects lying on the surface of the mud. It is proposed to

\footnotetext{
* Crawford (loc. cit.) pointed out that this identification was obviously an error: this opinion has since been confirmed from examination of Percival's actual specimens.
} 

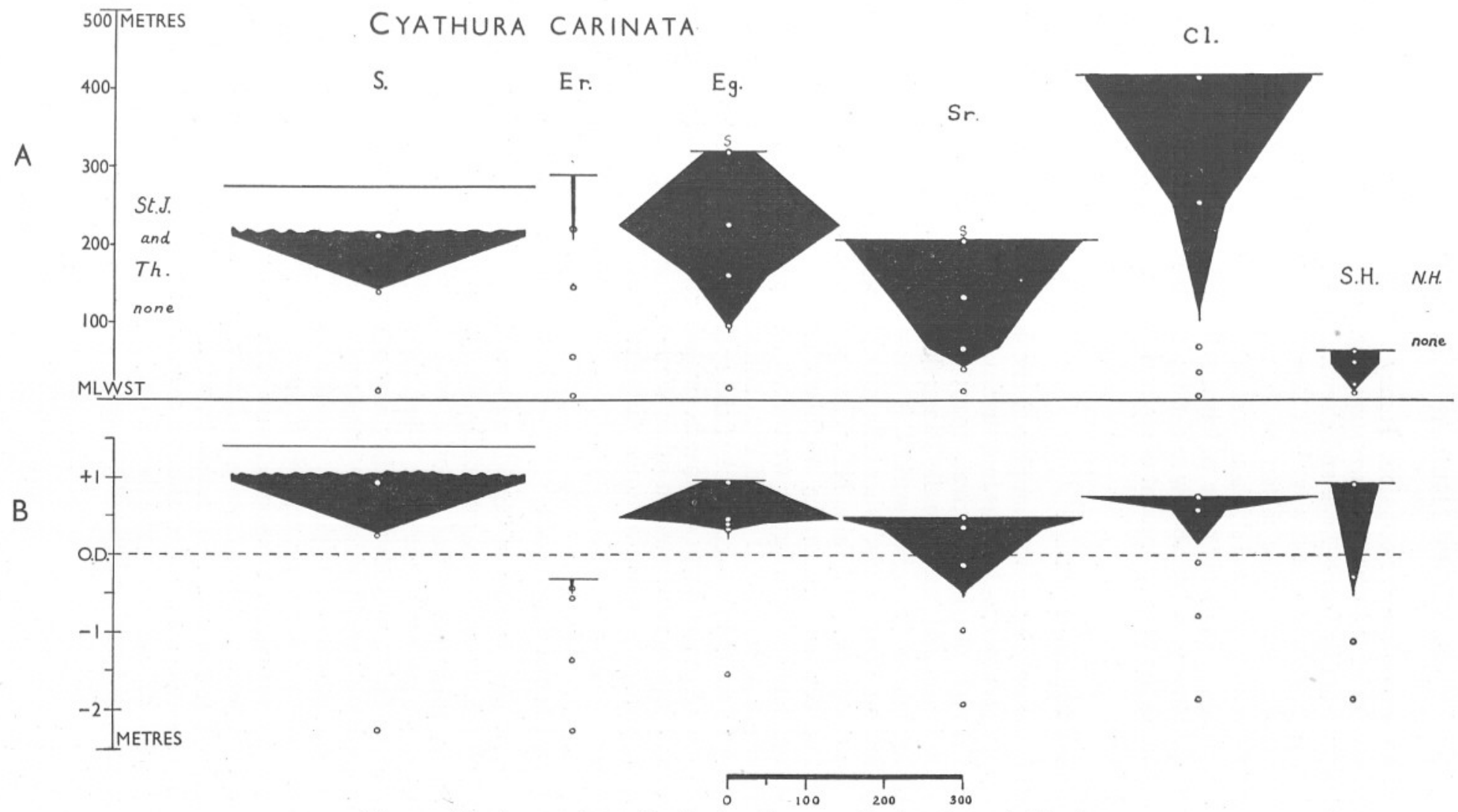

Fig. 1o. Cyathura carinata: distribution diagrams. Explanation as in Fig. 8. 
deal with them on another occasion. It may be noted, however, that the most marine species of the genus, $S$. serratum, figures in several samples, though irregularly, from St John's Lake and elsewhere. It occurred in any numbers only where there was a relatively thick deposit of old mollusc shells, among which it takes cover, at the surface of the mud-in two stations there were about 300 per $\mathrm{m}^{2}{ }^{2}$ As these shells are a regular component of the substratum, this Sphaeroma is probably quite widely distributed on the flats in the lower part of the estuary, at least below mid-tide; but its numbers must be mainly dependent on the varying amount of cover the surface of the ground happens to provide.

\section{Corophium volutator (Pallas).}

This is the only burrowing amphipod encountered. Though often present in vast numbers over wide areas in estuaries, and found abundant in the mud in the Calstock district (Percival, 1929; Crawford, 1937), it proved unexpectedly scarce and patchy on the Tamar flats up to North Hooe. Occurring almost throughout the region worked, it was only found in high numbers in one station on West Muds, where the number of all sizes retained by the sieve was I I,000 per m. ${ }^{2}$ (Table III). The species was seen to occur in plenty over a considerable area in the neighbourhood of this station, but failed almost completely a little farther westwards on the site of the main traverse. A comparison of stations D I and D 2 indicates that a growth of Zostera is unfavourable to it. The occurrence of the species in abundance in soft mud of salting pools, as at Egypt Saltmarsh, in sheltered brackish ditches, and in firmer sand-impregnated mud in other West-of-England estuaries, indicates that it is particularly sensitive to the disturbance of its substratum by water currents.

\section{Other Isopoda and Amphipoda}

The remaining species of isopods and amphipods which are included in the sampled fauna counts are essentially dependent on the presence of growths of Zostera, green algae, leaf deposits, or other vegetation which may be present at the surface of the mud. When the mud is bare over a wide area, these species fail completely; but they may occur casually on bare patches in the proximity of ground which provides a more suitable habitat. The numbers obtained indicate the sort of density in which these Crustacea may be expected where the cover is not dense, and where they are accessible to avian predators. Idotea viridis may occur in sparse clumps of filamentous alga, or in very thin growths of Zostera. A few Gammarus locusta or zaddachi may be present in the very sparsest of cover. G. zaddachi, which replaces locusta in the middle estuarine zones, occurs in some abundance among leaf deposits near low water, and young stages can exist where there is only a moderate deposit of fragmented vegetation in the surface layer of the mud. Melita palmata, which becomes 
abundant on stony ground, makes use of the shelter of old mollusc shells rather than of vegetation.

Carcinus maenas (Penn.).

It is probably because of their abundance in the estuary as a whole that the juveniles of the common shore crab figure so regularly in the fauna counts. Numbers are usually found under the cover of weeds and stones, but to some extent they also scavenge over the open mud (as can be observed in tidal pools), and take partial cover in the mud itself. To some extent the Carcinus population recedes with the tide (this has actually been observed), but the fall of the tide finds a number of individuals sparsely, but fairly regularly, distributed over the mud flats. The presence of any sort of object that can in any way provide cover tends to favour their occurrence. The highest population densities, of between 100 and 200 per m. ${ }^{2}$, were found in St John's Lake where there was a growth of Zostera or a surface deposit of shells.

\section{MOLLUSCA}

Hydrobia ulvae Peringia Pennant.

This very characteristic inhabitant of estuarine muds is more readily studied than most species dealt with here, owing to its habit of exposing itself freely on the surface after the tide has receded. The data secured from the sample counts are but a fraction of the information now available on the occurrence and habits of the species in the south-west counties. The references to it in the literature are also considerable. Only some of the more relevant facts can be dealt with here.

In the Plymouth district Hydrobia ulvae occurs in at least one locality on the shore of Plymouth Sound, but its occurrence in marine habitats is probably dependent on local freshwater influence. The estuaries, however, provide habitats in which it occurs in typical profusion. On the mud-flats of St John's Lake it is densely spread over many acres from West Muds to the very head of the "Lake" near St John. The population densities given in Tables I-III, and shown diagrammatically in relation to position on the shore and to tidal level in Fig. II, are noteworthy not only for their size but also for their regularity. A maximum concentration about the mid-tide level is indicated, with a rapid decline from the maximum during the first halfmetre below O.D. The decline upwards towards mean high water is more gradual, and the bulk of the population comes to be concentrated between the levels of O.D. and $+\mathrm{I} \mathrm{m}$. The density appears to be increased by the presence of growths of Zostera, etc., which provide an additional effective area of substratum, but the molluscs are conspicuously densely spread over wide areas of bare mud completely devoid of macroscopic vegetation. Inspection of the ground when the tide has receded long enough to allow the mud to settle and the Hydrobia to emerge to the surface shows that, at any given 


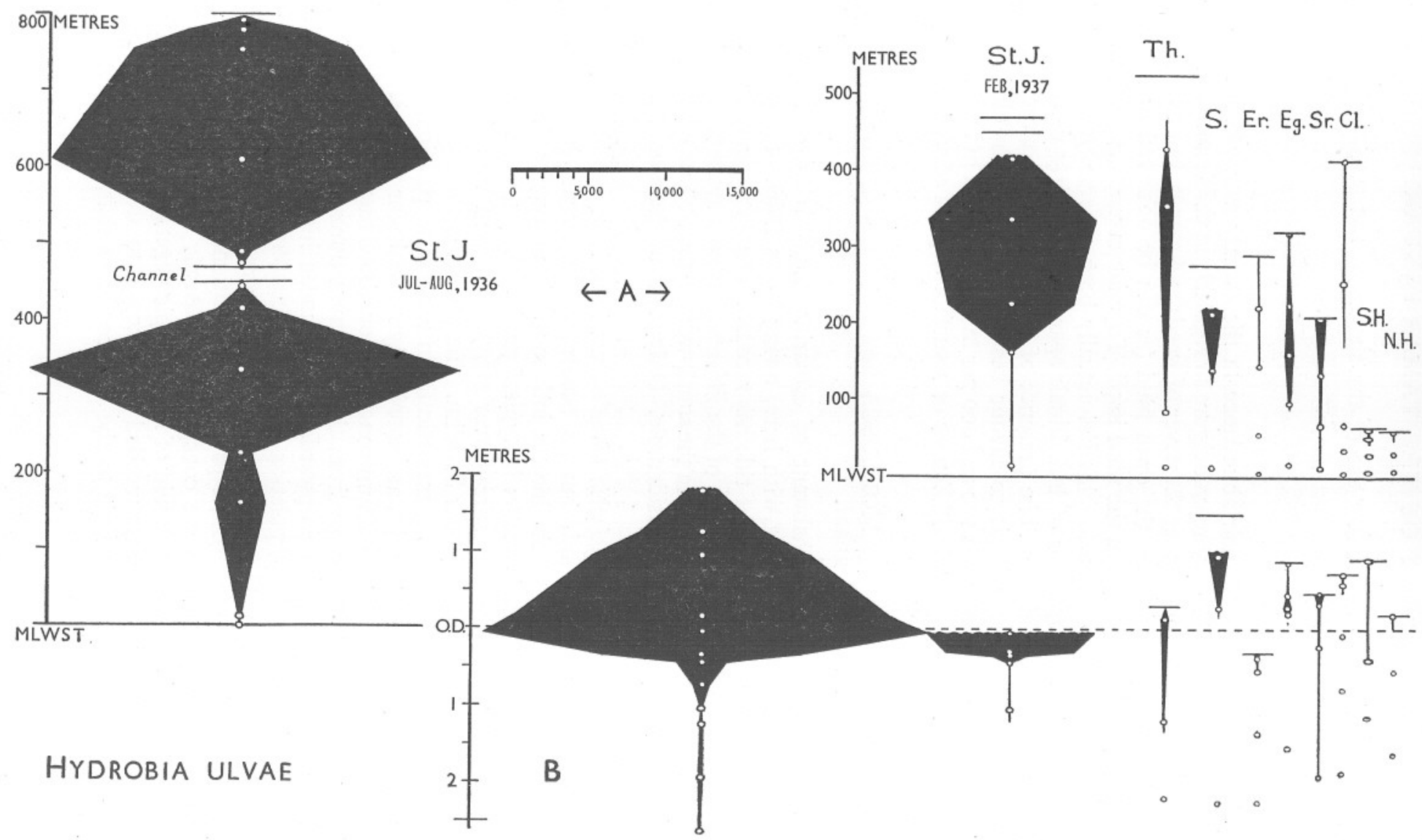

Fig. II. Hydrobia ulvae: distribution diagrams. Explanation as in Fig. 8. Note that, owing to space requirements, the left-hand pair of diagrams are not in alignment. 
level, the animals are remarkably uniformly distributed and almost independent of the nature of the surface of the ground. This may range from fragmented shillet*, provided silt is mixed freely with it, to bare soft mud.

At St John's Lake Hydrobia reaches its maximum abundance, and nowhere higher up the river were anything approaching the higher population densities encountered. The diagrams in Fig. II, however, exaggerate the extent to which the species declines up-river, as locally, in sheltered bays particularly, moderately dense populations occur. An example is Salt Mill Creek, where most of the mud-flat is occupied by a much denser concentration than the Ioo० per m. ${ }^{2}$ obtained at the top station on the river side of the salting. Relatively high numbers also occur on the flat south of Cargreen. North of Weirquay, however, inspection of the ground confirms the indication given by the traverse figures that the species is nearing the upper limit of its range on the mud-flats.

The distributions on the traverses from Thanckes Lake upwards all agree in showing a concentration above the mid-tide level, even though the population densities are small. The species was evidently scarcer above Cargreen than near Saltash, and scarcer still in the region of Clifton and South Hooe. At North Hooe, the highest limit previously recorded, only a bare indication of its presence was obtained. Sheviock Wood is given by Percival (I929) as its upper limit in the Lynher, and on the Tavy branch it reaches Gnatham.

The upper limit, however, has been observed to fluctuate from one year to another. In 1938 , after a long period of deficient rainfall early in the year, with resulting decrease of freshwater influence in the estuaries, definite signs of up-river extension of range were noted in three localities:

(i) River Tamar: on the mud-flats bordering Egypt Saltmarsh, much more numerous in 1938 than 1937 (and marked decline in 1939). (ii) River Tavy: in June 1937 none above Bere Ferrers and still very sparse I km. distant below, whereas in summer 1938 it colonized the flats at least up to Gnatham. (iii) River Yealm: none seen in Cofflete Creek above Steer Point in I937, but quite numerous up the creek in 1938.

The account of the distribution of Hydrobia ulvae would not be complete without reference to its partiality for a habitat which differs in many respects from the intertidal mud-flats. The extent to which it dominates in salt-marshes is apparently not generally realized. In salting "meadows" (typically a closed association of grasses, sea-plantain, etc.) it may be collected in large numbers from the damp mud around the bases of the grasses, etc., and is apt to congregate thickly in the damper, but more open, depressions. During I937 the species was observed in salting "meadow" habitats in West Sussex, Norfolk, Lincoln, and Cornwall (River Camel), as well as in the Tamar Estuary, as for example at Egypt Saltmarsh (see also Rothschild, I938). The animals

\footnotetext{
* A local term applied to the clay-slate of which the geological strata mainly consist.
} 
here are subject to long periods of exposure to the air, as salting meadows are typically only covered by spring tides. Conversely, their abundance and flourishing condition in many salting pools shows that they are capable of tolerating permanent immersion. In the course of her studies on its trematode parasites, Rothschild (1936, 1938, and 1939) has brought to light several interesting features of the biology of this mollusc. Of these it may be noted here that in salting pools and damp hollows in saltings much greater average sizes are attained than on the mud-flats: in both situations infection by trematode parasites tends to increase growth above the normal for the habitat. The growth conditions amongst the grass of saltings also appear to be superior to those on the mud-flats. Analysed samples from St John's Lake and Egypt Saltmarsh show this contrast well; but when specimens from the two localities were reared in the laboratory under similar favourable conditions, the growth-rates were found to be identical, proving that the environment is wholly responsible for the difference (A. and M. Rothschild, I939).

The tendency for Hydrobia ulvae to concentrate in the upper part of the tidal zone is apparently a general phenomenon. It is shown, for instance, in a traverse of eight stations worked by Stephen (1930) across the shore of Loch Gilp. Lambert (1930) remarks on the long periods of exposure to which the species is subjected on the mud of the Thames Estuary, and goes so far as to express the opinion that it requires exposure to the air for at least 20 out of the 24 hours. The precise data given by Thamdrup (1935) for a traverse at Skalling, Denmark, over a period of years, show a regular and usually very high maximum about mean high water, between +0.5 and $0.6 \mathrm{~m}$., and an abrupt diminution between that level and half-tide. Wohlenberg (1937), in his survey of a bay in the north of Sylt, records $H$. ulvae generally distributed in the upper third of the tidal zone. Similar conditions to those observed at St John's Lake-dense concentration above half-tide and disappearance towards low water-have been observed by inspection of the ground in other English localities, among which the upper part of the Salcombe Estuary and the mud-flats near Blakeney (Norfolk) deserve particular mention.

The higher population densities found on St John's Lake seem to be fairly typical for the optimum intertidal environment. A summary of other figures for comparison is listed below (Table IX). Especially useful data are given by Nicol (1935) and Thamdrup (1935). The very high maximum densities found by the latter are confined to a narrow zone in the region of high water. No attempt was made at St John's Lake to seek out the densest patches at the most favourable season, and it is not improbable that densities approaching the maximum recorded may occur. Nicol's figures are the only ones available for salting pools; but the concentrations which have been observed in favourable pools suggest that counts would have compared closely with those from optimum zones on intertidal muds. 


\section{Table IX. Population Densities of HydRobia ULVAE}

Author

Thamdrup, I935

"

"

Stephen" I930

Nicol, I935*

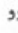

Spooner \& Moore (unpublished)

Serventy, I934
Locality

Skalling, Denmark$$
\text { " }
$$$$
\text { " }
$$

Loch Gilp, West Scotland Tynninghame, Firth of Forth

Aberlady, Firth of Forth

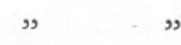

g

,

,

Poole Harbour, Dorset

Scolt Island, Norfolk

"

"

\section{Habitat}

Wide flat of muddy sand

$\begin{array}{cc}" & \\ \prime & " \\ " & " \\ \text { Muddy sand } & \text { " }\end{array}$

Soft estuarine mud

Bare estuarine mud

Tidal sandy pools

Clean estuarine sand

Salting pools

Soft mud

Brackish muds
Particulars of estimate

Maximum in thickest patches discovered

Maximum on traverse,

March 1934

Do. July I932

Do. July I 933

Do. Oct. 1933

Do. July I93I

Do. Aug. 1934

Maximum on traverse

One sample of $1 \mathrm{~m}^{2}$

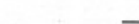

Selected dense patches,

maximum

Normal high counts

Highest figure obtained

One station at $+\mathrm{r} .09 \mathrm{~m}$.,

probably above optimum

zone for species

Estimate of highest

density

Estimated normal high
density

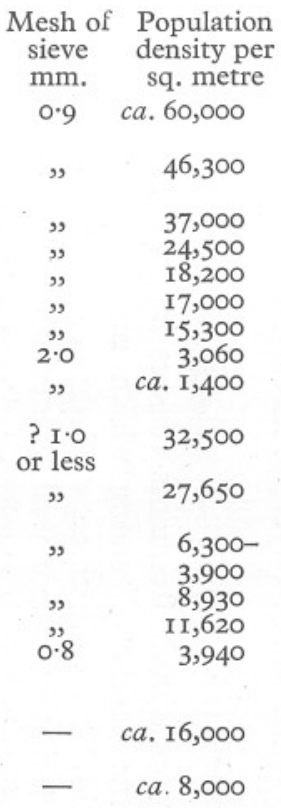

* Nicol's figures are given in numbers per square foot and have been converted. 
Littorea littorea (L.).

The Common Winkle frequents various intertidal habitats in estuaries as well as on the seashore, among which mud-flats are included. Though inclined to cluster round clumps of algae, or other objects which provide cover, it is often to be seen well scattered over open bare mud. At best, however, its distribution is patchy, and sampling on a wider scale would be necessary for population counts which could be related to tidal level irrespective of other factors.

On the grounds sampled it was found in abundance only on St John's Lake, ranging almost over the whole tidal zone from high-water neaps even down to low-water springs on suitable ground. The range of population densities of o-480 per m. ${ }^{2}$ gives an indication of its patchiness, the two highest figures being obtained from ground which contained the highest admixture of old mollusc shells. At the station with 480 per m. ${ }^{2}$ no fewer than 346 belonged to the larger sizes (second and higher year groups). The biology of this species on St John's Lake, where until the recent restrictions it was regularly collected by fishermen, has been dealt with independently (Moore, I937a). Population counts have also been made at known levels on the algacovered shore near Torpoint opposite West Muds (Moore, I939). In this habitat the species is more evenly distributed, from high-water neaps to low water, and shows the same maximum concentration between mid-tide and low-water neaps as is typically found on the sea coast. If allowance is made for patchiness, the data for the St John's Lake flats (Tables I-III) indicate a similar distribution.

Higher up the estuary L. littorea is mainly restricted to the local patches of stony ground, but on the flats along Ernesettle embankment it was observed to be generally, though sparsely, distributed. The traverse figures here indicate a density of the order of $\mathrm{I}$ or 2 per $\mathrm{m} .{ }^{2}$ Its upper limit in the estuary is not far above this point: while still numerous near high water at Neal and Lime Points on stony ground, it occurs regularly, though sparsely, under the cover of weeds on Thorn Point Causeway, but has never been found in the Weirquay district or above. Many empty shells are washed up along Egypt saltmarsh, but very few higher up. Antony Creek is given by Percival (I929) as its upper limit in the Lynher. A comparable degree of penetration up-river is evident in the Exe (Allen \& Todd, 1902), Tees (Alexander et al. 1935), Mersey (Bassindale, I938), and other estuaries.

Among the numerous scattered papers which deal with the ecology of L. littorea, estimates of population density are sometimes included. The density on open ground appears usually to be of an order of I/IO of that attained where fucoids, mussels, stones, or other objects provide suitable cover. Investigating the mud-flat winkle grounds of the Blackwater Estuary (Essex), Wright (I936) made four sample counts of patches amounting to $2 \frac{1}{2}-3 \mathrm{~m} .^{2}$ The average total numbers per $\mathrm{m}^{2}$ of all sizes above $3 \mathrm{~mm}$. lay between I2 and 39. Thamdrup (1935) records a density of 330 per $\mathrm{m}^{2}$ on 
a mussel bed below mid-tide, but much lower numbers, when the species occurred at all, on barer ground. In a series of counts along the sea-wall of the River Tees (Alexander et al. I935), in which the average of six counts of one $\frac{1}{4} \mathrm{~m} .{ }^{2}$ at each station was taken, the highest figure derived was just on 300 per m. ${ }^{2}$ Fraser's data (I932, Table VIII) for a locality in the Mersey Estuary indicate the usual kind of patchiness: about half the samples of $\frac{1}{16} \mathrm{~m} .{ }^{2}$ patches contained none, others several $L$. littorea, up to $32\left(=5 \mathrm{I} 2\right.$ per $\left.\mathrm{m} .{ }^{2}\right)$.

Littorina saxatilis (Olivi) [=rudis (Maton)].

This species occurred in company with the above on St John's Lake, in numbers up to I Ioo per m. ${ }^{2}$ Here it appears almost confined to levels between high water and mid-tide, its usual optimum zone on the shore (see, e.g. Moore, I939). The low level of Ernesettle flats probably accounts for its absence on that traverse, for its upper limit in the estuary appears almost identical with that of L. littorea. Though not recorded from Cargreen, it is fairly plentiful at Lime Point. Published data on the occurrence of $L$. saxatilis in estuaries are extraordinarily scanty: even if scarcer on the whole, it is liable to be overlooked when mixed with the young of the larger species. In spite of having an optimum high up the tidal zone, it tolerates permanent immersion. Thus it abounds in the shallow brackish waters of the Fleet, Dorset; and Howes (I939) records it swarming on Ruppia in a saline Essex creek.

\section{Cardium edule L.}

The Common Cockle occurs regularly in muds in the seaward half of the estuarine zone, inhabiting all levels from mean high water to the permanent river channel. Like other species already considered which occur only in the seaward half of the estuary, it showed a maximum density at St John's Lake. In this region it is a dominant member of the fauna. Though apparently more consistently plentiful between high-water neaps and mid-tide, it shows no marked optimum that can be related with any confidence to tidal level (Fig. I2). The variation among the population densities of different stations seems attributable mainly to the nature of the ground. Thus a growth of Zostera seems favourable, as well as a high admixture in the surface layer of the mud of dead mollusc shells; while on the other hand Cardium is scarcer on soft slopes which are scoured by tidal currents. No greater regularity of distribution is shown by the larger sizes ( $\mathrm{I} \mathrm{cm}$. length and over) when the obviously irregularly distributed young are deducted. The population densities found for larger sizes vary up to 93 per $\mathrm{m}^{2}$ For all sizes retained by the sieve, that is from ca. $0.15 \mathrm{~mm}$. length and over, 383 per $\mathrm{m}^{2}$ was obtained at one station where there was an unusual number of young, but between 100 and 200 per m. ${ }^{2}$ was more usual for typical "good" grounds. A comparatively dense concentration of very large specimens on the edge of West Muds (station D 4) is noteworthy. 
In succeeding traverses up-river very small numbers of cockles were obtained. From Thanckes Lake to Salter Mill sizes above I $\mathrm{cm}$. length appear either absent or rarely present above one individual per $\mathrm{m}^{2}$ Smaller sizes are somewhat more frequent: 40 per m. ${ }^{2}$ occurring at low water at Salt Mill, and 36 per m. ${ }^{2}$ in one station at Salter Mill. The species appeared entirely absent on Clifton Flats and above. That Weirquay marks the upper limits of its range in the Tamar is confirmed by other observations, and in the Lynher it occurs at least up to Sheviock Wood. These limits coincide with those of Nephthys hombergi. Compared with other dominant species, Cardium edule penetrates somewhat farther than Littorina littorea, but not so far as Hydrobia ulvae.

It is of interest to enquire whether the population density of the cockle on St John's Lake approaches the maximum attained by the species. In none of the stations worked on various types of ground in different localities on the Scottish coast by Stephen (1929, 1930, 1932) was a density found which, making full allowance for his use of a $2 \mathrm{~mm}$. sieve, exceeds the higher values for St John's Lake. Thamdrup (1935), however, found much higher densities on his traverses at Skalling, where Cardium edule proved the most abundant of all animals by weight, and was only exceeded by Hydrobia ulvae in numbers. One traverse, worked by him on seven occasions between July I93I and November 1934, gave population curves which consistently show a scarcity of cockles at the highest levels (the zone of maximum abundance of Hydrobia), but regular high numbers over the rest of the traverse with a maximum nearly always just above mid-tide level. The maximum densities found, which do not include the o-year-group, vary from 4675 to 1360 per m. ${ }^{2}$ As Stephen (I93I) found in Scotland, the average size tended to increase towards low water. On the second traverse cockles were scarcer, but even here a density of I 500 per m. ${ }^{2}$ was obtained. Evidently, then, the conditions on St John's Lake fall well short of the optimum for the species.

Scrobicularia plana (da Costa).

Abundant generally in estuaries in the south and east of England (but scarcer and more local in the north), in varying types of ground, this lamellibranch is particularly characteristic of intertidal brackish muds. Unrecorded from the open shore in South Devon, it occupies a wide range in estuarine zones. In the Tamar it occurs from St John's Lake up the main river to North Hooe, up the Lynher branch to above St Germans (Percival, I929), and up the Tavy to Maristow. In the Salcombe Estuary the species begins to appear sparsely at Salcombe, becoming more common near Snape's Point (Allen \& Todd, I900), and is plentiful higher up. In the Exe, Allen \& Todd (I902) found it in abundance, mainly in stiff mud, with a lower limit very near the mouth. In estuaries of the Plym, Yealm, Erme, Avon, and Camel, it has been noted as extending well above the limits of Cardium edule. Unlike Cardium, it appears more or less intolerant of permanent immersion. 


\section{CARDIUM EDULE

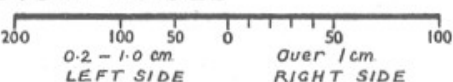

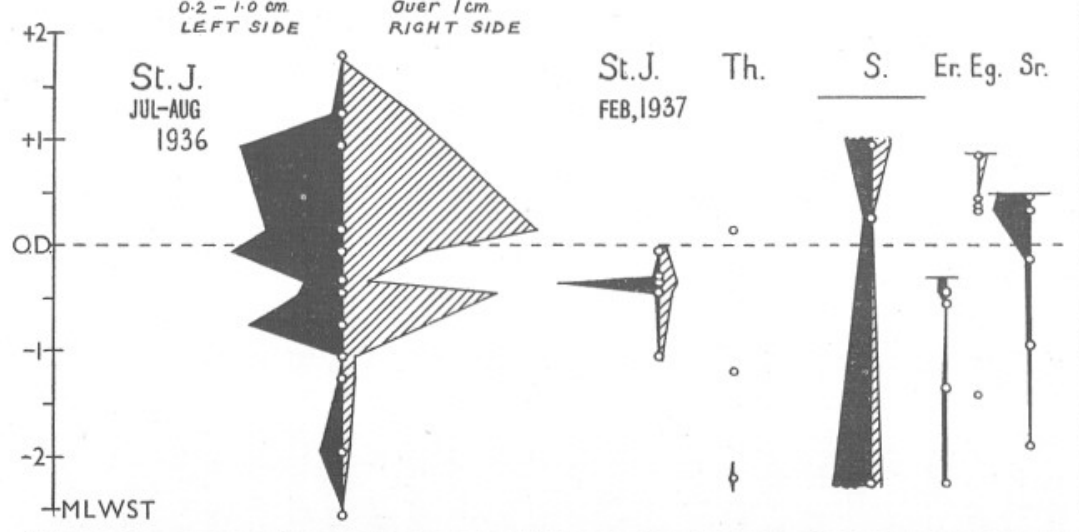

MACOMA BALTHICA
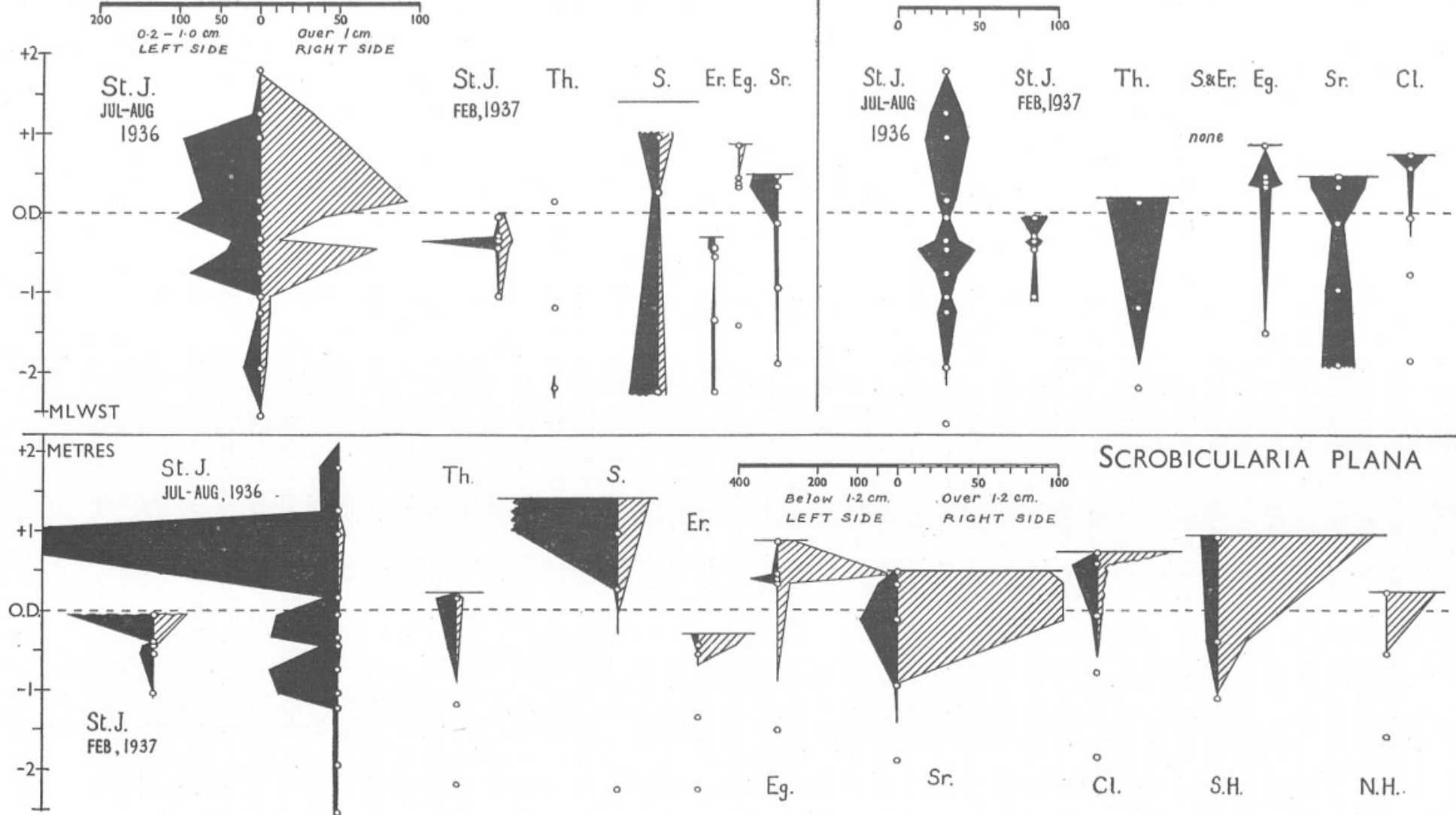

Fig. I2. Distribution diagrams for Cardium edule, Scrobicularia plana, and Macoma balthica, population density shown in relation to tidal level only (row B in previous figures). With Cardium edule and Scrobicularia plana the numbers of the smaller sizes are plotted on the left-hand side of each diagram (black) and the larger sizes on the right (cross-hatched). With Macoma balthica the usual total numbers are plotted. Remaining explanation as in Fig. 8. 
The regularity with which it occurred in the mud samples emphasizes the prevalence of this species in the Tamar. Since it seems improbable that it is greatly affected by the sort of variations in the substratum that were encountered; and since, further, the population seems to contain sufficient year-groups to mask the effects of annual fluctuations in recruitment, the data from the traverses may be expected to show up more clearly than usual the general features of the species' distribution.

In the counting of the samples, the Scrobicularia were separated into five size groups (Tables I-VIII), the lowest group of below $0.5 \mathrm{~cm}$. length consisting entirely of first-year spat. It may be noted that these smallest sizes have fragile shells which crush very easily if sieving operations are at all drastic: it would have been impossible to have obtained the whole population of young Scrobicularia intact without the "souping" methods employed for dealing with the mud. Specimens of the two larger size-groups $(2-5 \mathrm{~cm}$. in length) often burrow to depths exceeding $10 \mathrm{~cm}$. Where pointed out in the tables specimens of these sizes were liable to be lost owing to the shallow depth to which the sample was dug, and due allowance must be made for this fact when the results are compared.

From the tables and Fig. I2 it will be seen that Scrobicularia occurred in every station worked on the St John's Lake grounds, showing that here it ranges from mean high-water to low-water springs. The mollusc, however, is consistently absent below the $-\mathrm{I} \cdot 0 \mathrm{~m}$. level on all other grounds up-river. Whether total numbers, or the larger sizes alone, are considered, the species tends to be concentrated in the upper half of the tidal zone down to just below mid-tide level. Where the presence of saltings limits the extent of the mud-flat, the species may be traced in salting creeks well up into the highwater zone. The actual optimum level may vary somewhat. There is an indication that the decline at the lower range of the intertidal zonation sets in at an increasingly higher level up-river.

A remarkable feature is brought out when the distributions of the different size groups are compared. Specimens of below $\mathrm{r} \cdot 2 \mathrm{~cm}$. length (which approximately includes the $\mathrm{O}$ and I year groups) occur in highest numbers in the lower part of the range of the species, especially on St John's Lake, where six stations produced more than roo per m. ${ }^{2}$, and one actually over Iooo per m. ${ }^{2}$ On this ground these small sizes, chiefly composed of the smallest group of below $0.5 \mathrm{~cm}$. in length, comprise the bulk of the Scrobicularia population. For here, by contrast, the larger sizes are relatively very scarce.* The populations obtained at Thanckes Lake and Salt Mill were still mainly composed of the smaller sizes, but for the first time at Salt Mill and Ernesettle the density of the sizes above $2 \mathrm{~cm}$. length exceeded ro per m. ${ }^{2}$ The optimum zone was reached at Salter Mill, where a dense population was encountered

* This statement makes due allowance for the inadequate sampling of the largest sizes in several stations. Tests have been made digging deeper in the mud; the scarcity of burrows can be seen by examining the ground; old shells are considerably less plentiful than up-river; and the middle size-group ( $1 \cdot 2-2 \mathrm{~cm}$.), most of which would have been collected, is very scarce, 
in which all sizes were well represented. There the larger, above $2 \mathrm{~cm}$., reached 84 per m. ${ }^{2}$ in two stations; and an average density, for these sizes, of at least 75 per $\mathrm{m}^{2}$ is indicated for the whole flat from the salting edge to the -0.5 level. In this part of the river the star-shaped impressions which mark the burrows are conspicuously numerous on the surface of the mud. The mud at South Hooe appeared on inspection to be another good Scrobicularia ground, and here another well-balanced population was obtained in the samples. At North Hooe only some large specimens of over $3 \mathrm{~cm}$. were obtained in the upper sample: this locality is at, or very near, the upper limit of the mollusc's range.

The indications, then, are that the conditions for settlement of the spat are most favourable at the lower limit of the range of the species, but that growth conditions are at an optimum much higher up the estuary. This optimum zone coincides with the very upper limit of penetration of Cardium edule and Nephthys hombergi, and approximately coincides with the optimum for Cyathura carinata.

It would appear that the great majority of the spat which settle on St John's Lake die off naturally at an early age. A more striking example of this phenomenon has been observed in the Fleet, Dorset. In the Langton Herring district vast numbers of spat settle in shallow water on mud-bearing growths of Zostera hornemanniana and Ruppia. Though sizes of below $0.6 \mathrm{~mm}$. length can be collected in great abundance, not a single larger specimen could be found. Every year the tide marks of the Fleet are strewn with myriads of the small-sized valves, but the valves of larger sizes do not occur. The tidal zone is for the most part gravelly and unsuitable for settlement, and if it is indeed true that intertidal conditions are necessary for the survival of the spat and growth of the adult, a partial explanation is provided. If this is so, a different factor must be operating on St John's Lake: the high salinity seems by far the most probable.

The literature relating to the biology of this abundant species is surprisingly meagre. In Britain at least it is essentially an intertidal species of waters of reduced salinity, and typically fails in permanent standing water or below the tidal zone. Few estimates of population density have been made. Stephen (I930) records 136 per $\mathrm{m}^{2}$ retained by a $2 \mathrm{~mm}$. sieve in one mud sample from Firth of Forth; while Thamdrup (1935) throws some light on its behaviour at the very seaward end of its range (in West Denmark). On one of his traverses the species occurred very sparingly about mid-tide level in I93I and 1932, and then somewhat more plentifully in I933, when it was distributed from just above mid-tide level to low water (only small specimens below mid-tide). In 1934 there was a bigger spat-fall still. The complete absence of the species, even in the latter year, from the higher tidal levels, across $200 \mathrm{~m}$. of flat, may be noted.* Evidently the salinities were still too

* Wohlenberg's (I937) data from Sylt shows agreement: in I932 the species was very scarce on the area surveyed, but in 1934-6 became common on suitable ground. No precise data, however, are given on densities or tidal levels. 
high to enable the Scrobicularia to colonize the upper part of its normal intertidal range, as it is already just able to do in the Tamar at St John's Lake.

A density of 58 per m. ${ }^{2}$, of which 24 were below $0.5 \mathrm{~cm}$. length, was found in one sample of sheltered soft mud near the mouth of Poole Harbour.

\section{Macoma balthica (L.).}

In the south-west of England this species is typically greatly outnumbered by the above, and appears never to attain a dominance comparable with that in some localities in North England and Scotland. In the Tamar, though very widely distributed, it is everywhere relatively scarce. On St John's Lake it was absent from only five out of twenty-four stations, but never exceeded a density of 36 per m. ${ }^{2}$ The highest density recorded was 76 per m. ${ }^{2}$, of smaller sizes below I cm. length, at Thanckes Lake. Still present at Salter Mill, where it occurred in all five stations with a maximum of 36 per m. ${ }^{2}$, it reached an upper limit on the Clifton flats.

The species proved to be fairly uniformly distributed through the tidal zone (Fig. I2), and distinctly more tolerant of low-water conditions than Scrobicularia, especially in up-river localities.

At the time this work was carried out there was an almost complete absence of the spat of this mollusc. Specimens collected tended to fall in groups of similar size, with marked gaps between the groups. The evidence indicates that appreciable recruitment of the population occurs only in favourable years.

Conditions in the Tamar are evidently adverse for Macoma. The sizes attained, judging both from living material and cast-up valves, are well below those which the species is known to attain elsewhere. Also far higher densities occur where the species thrives. Thus, in the Firth of Forth, Stephen (1929, I930, I93I) found that the denser populations reached I50-200 per m. ${ }^{2}$ (highest sample 288); Thamdrup (I935) found up to I000 per $\mathrm{m}^{2}$ and a maximum of no less than $6325 \mathrm{~g}$. per m. ${ }^{2}$ by weight; while in the Mersey (Fraser, 1932; Bassindale, I938) it is the commonest bivalve, occurring at great abundance in places, especially in thick mud, almost completely displacing Scrobicularia, and attaining densities as high as 5900 per $\mathrm{m}^{2}(2.5 \mathrm{~mm}$. sieve).

\section{Abra nitida (Müller) and Abra prismatica (Montagu).}

Both of these species occurred in small numbers near low water only, at the seaward end of the estuary. A. nitida occurs along the edge of West Muds, where it has been collected on several occasions, following the main St John's Lake Channel at least as far as B 6. A. prismatica appears restricted to the edges of the tributary channel (having occurred at A 6, B 4, and C) (Fig. I), at the mouth of which it mixes with other species. It was also present at the two lowest stations at Thanckes Lake.

Both species are essentially marine, but evidently able to tolerate a lowering 
of salinity which might enable them to penetrate considerably farther up the estuary in the upper tidal levels. But their distribution in purely marine habitats shows them to be intolerant of intertidal conditions. It may be noted that much of the zone they inhabit-soft unstable mud on the channel slopes-supports a very sparse fauna.

\section{Discussion}

By way of summarizing the main features of the distribution of the principal species encountered Table $\mathrm{X}$ has been drawn up. The species are conveniently separated into three groups. Group A includes those which thrive in marine habitats where the salinity of the water is more or less full strength, but have a greater or lesser toleration of water of reduced salinity, and penetrate to varying extents into estuaries. Group B includes species which, though occurring freely in marine habitats, have a decided preference for water of reduced salinity, and are on the whole better known as estuarine than marine animals. In the Tamar only two species (possibly three, if Heterocirrus sp., omitted from the table owing to imperfect information, can be included) fall in this group, and for one of these, Nephthys hombergi, there is evidence that its optimum zone is not in the sea, but where the salinity is appreciably reduced (p. 306). Group C includes species which are predominantly estuarine, and which, if they occur in more or less purely marine habitats, do so irregularly in much reduced numbers. Of the five species of this group encountered in the Tamar, Hydrobia ulvae is most nearly connected with the previous group.

The first two columns in Table $\mathrm{X}$ refer to the extent and degree of penetration into the Tamar Estuary. It is not surprising to find all the species of Group A occurring in greatest numbers at the lower end of the estuarySt John's Lake-and either disappearing or steadily decreasing above this point. The majority, if not all, may be expected to find their optimum environment in the sea or at least in more truly marine conditions than those which hold for St John's Lake. In Group B, Nephthys hombergi appears to find its optimum a little way inside the estuary; and in Group C optimum conditions are of necessity found somewhere in the estuarine zone-one (Hydrobia) low down, at St John's Lake, one (Corophium) apparently diffused over a very wide stretch of river in which dense patches occur as far apart as West Muds and Calstock, and three others with a definite optimum well up the river. As regards extent of penetration, Group A species disappear somewhere in the lower half of the estuary, with the exception of the juveniles of Carcinus maenas; Group B reach to about half the length of the estuarine zone ( $15 \mathrm{~km}$.); and Group C pass beyond $\mathrm{I}_{5} \mathrm{~km}$. into the upper half.

It is not proposed to discuss further the subject of up-river penetration, as this is best deferred until other sections of the fauna can be surveyed. It must be emphasized that the marked tendency for most species to concentrate 


\section{Table X. Summary of Data Relating to Species which Inhabit Mud-Flats of the River Tamar}

\begin{tabular}{|c|c|c|}
\hline & $\begin{array}{l}\text { Approximate } \\
\text { position of } \\
\text { maximum } \\
\text { abundance } \\
\text { in Tamar }\end{array}$ & $\begin{array}{l}\text { Relative } \\
\text { penetration } \\
\text { up Tamar } \\
\text { Estuary (in } \\
\text { km. from }\end{array}$ \\
\hline nei & Estuary & mouth)^ \\
\hline
\end{tabular}

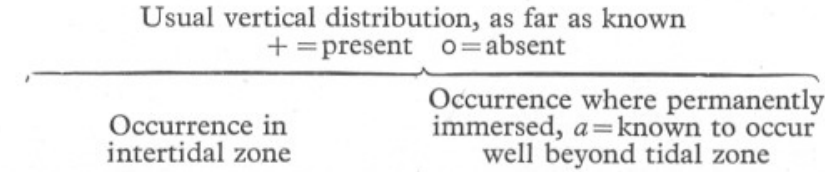

\section{A. ESSENTIALLY MARINE SPECIES}

Abra prismatica Abra nitida Ampharete grubei Mellina palmata Phyllodoce maculata Cereus pedunculatus Lanice conchilega Scoloplos armiger

Carcinus maenas juv. Littorina littorea

St John's Lake St John's Lake St John's Lake St John's Lake St John's Lake St John's Lake St John's Lake St John's Lake

St John's Lake St John's Lake

ca. 28
I I

St John's Lake

Littorina saxatilis

Io

Cardium edule

St John's Lake

13.5

Nephthys hombergi

Thanckes Lake

Macoma balthica

No marked maximum

Hydrobia ulvae

St John's Lake

I 8.5

Not typically intertidal

Lower part of tidal zone-

Lower part of tidal zone:

Greater part of tidal zone:

At and near low water

Throughout tidal zone (p. 306)

Shallow water

Throughout tidal zone

Through tidal zone, maximum below mid-tide

Mainly shallow water

Usually o (see Colman, I933)

Maximum mid-tide and above

Not in sea, but in shallow brackish waters and tidal pools Throughout tidal zone Mainly shallow water

\section{B. MARINE AND ESTUARINE SPECIES}

13.5 Usually in lower part of tidal

$$
\text { zone }
$$

Relatively uniform through tidal zone, sometimes maxima about mid-tide

General below tide-marks, but chiefly shallow water

\section{MORE OR LESS STRICTLY ESTUARINE SPECIES}

Corophium volutator

?

ca. 27

Typically concentrated in upper half of tidal zone (pp. 3II-I4)

Cyathura carinata

Salter Mill

Scrobicularia plana

Salter Mill

Nereis diversicolor
North Hooe

\section{$\mathrm{I} 5+$ ?} high water

\section{I $8 \cdot 5$}

ca. 24
In shallow salting pools, and sometimes in small numbers below tidal zone

In shallow pools and sheltered ditches, etc.

$$
+\ddagger
$$

Usually 0

In various types of permanent (brackish) waters
Intertidal distribution found in River Tamar

At low water only

At low water only

Lower half of tidal zone (Fig. 8)

Lower half of tidal zone

? Scattered

? Scattered

Around low water only

Where occurs, only known

from above mid-tide

Scattered

Through tidal zone, with indications of maximum below mid-tide

Concentrated above mid-tide line

Scattered (Fig. I2)

Mainly in lower half of tidal zone (Fig. 9)

Scattered through tidal zone (Fig. 12)

Marked concentration midtide upwards (Fig. II)

(As far as known, maximum in upper half of tidal zone)

Concentrated, and almost confined, above mid-tide (Fig. Io) Concentrated above mid-tide (Fig. 12)

Concentrated above mid-tide throughout range except at extreme seaward end (Fig. 8) 
at certain tidal levels, found here to apply even to the mud fauna, shows how essential it is to consider tidal levels when the faunas of successive localities up the river are compared.

The other aspect of distribution studied (and the rest of the data in Table X) refers to the "vertical" range of the species, that is to say their relation to tidal level. The tendency for many shore animals to show preference for certain regions of the tidal zone is elementary knowledge. Some species maintain their relation to tidal level irrespective of changes in the substratum. Such zoning of Littorina spp., for instance, appears well established. But as a rule it is by no means clear, when intertidal zoning is found, to what extent it is due to changes in the substratum which more often than not accompany changes in tidal level. This consideration applies more especially to the fauna of bottom deposits, particularly burrowers. It is not often that such a uniform mud substratum from high to low water is found as provided by the flats of the River Tamar. The deposits of most estuaries contain a considerable content of sand particles, the presence of which results in a horizontal gradient between soft mud and clean sand down the length of the estuary, and also tends to produce a similar gradient vertically down the shore. The unusual lack of sand in the Tamar, making for a relative uniformity in the mud deposits, simplifies the study of intertidal zonation as well as of horizontal distribution.

It has been seen that most species for which there are sufficient data show some degree of concentration towards one part or another of the tidal zone. Tendencies of this kind which appear to be consistent are stated in the last column of Table $\mathrm{X}$, the two previous columns giving for comparison a brief summary of the normal habits of the species, as far as is known. For the marine species of Group A, the normal distribution on the sea coast can be considered apart from the behaviour shown in estuaries. The list for this group includes species showing all types of vertical distribution. If the last column is examined, it is seen that, as far as the data go, the distribution found in the Tamar is in essential agreement with that normally found on the open shore. There is only one species (Scoloplos armiger) which may have a more limited vertical range than it has at its optimum (see p. 306). In Group B, Nephthys hombergi, which at the marine end of its range is rarely found except at or below low water, maintains its preference for lower levels up the estuary. Similarly Macoma balthica, which appears normally to range fairly uniformly through the tidal zone on suitable ground (Stephen, I929, I930; Thamdrup, I935), was found in the Tamar more evenly distributed between high-water neaps and low-water springs than most species.

For the five estuarine species of Group $\mathrm{C}$, it is only possible to give a summary of their distribution in other brackish waters for comparison with that found in the Tamar. The data given are based on the discussion of the individual species earlier in the paper. For three of them there is almost nothing previously known of their optimum intertidal levels. The striking 
point about their vertical distribution in the Tamar is that all five species show a very marked preference for the upper part of the tidal zone, whereas of the fourteen species in Groups A and B only two at the most show a comparable preference. The three species in the latter groups which penetrate farthest up the river, and with which comparison is possible, behave otherwise: Nephthys is concentrated below half-tide, while Cardium and Macoma showing no marked optimum are at least more tolerant of the environment near low water than the five species of Group C. The contrasts between the former and Nereis, and between the two latter and Scrobicularia, may be noted. It is furthermore noteworthy that the species of Group C show this preference for levels above half-tide irrespective of their degree of tolerance of immersion. Scrobicularia plana is the only one of them for which there is any evidence that conditions approaching permanent immersion may be unfavourable.

Such are the data which present themselves for interpretation. There is evidently sufficient zoning shown by certain members of the estuary mud fauna to require explanation. It is impossible at this stage, and beyond the scope of this paper, to embark on an adequate consideration of ecological limiting factors. This will be more suitably done when a wider range of species can be considered, and when further laboratory and field observations have been carried out. But it is desirable to call attention to a few relevant points regarding this problem.

Since all intertidal species (with the exception of insect larvae, which are not dealt with on account of their scarcity) are aquatic organisms, the decrease and final absolute limit towards high water, at whatever levels these occur, are bound to depend partly, if not entirely, on the various adverse effects which accompany decreasing immersion and increasing emersion. Other influences which may also sometimes come into play-e.g. of the salinity, as mentioned on pp.327-8, or lack of adequate currents for plankton or deposit feeders-will be detected with difficulty, and as likely as not be completely masked. But as regards a downward decrease, when this is shown, from a maximum within the tidal zone in the direction of low water, there is no causal influence which operates universally. The species which show this effect include several which are perfectly able to tolerate permanent immersion. Other causal factors have to be looked for, and probably several operate separately or in conjunction. The elucidation of these seems to us to be the most significant aspect of the problem raised.

Whatever other influences are at work in the Tamar, there is one which we have good grounds for believing to be of importance and to affect most species in varying degrees. This, namely, is the effect of tidal and river currents. Bottom deposits of soft mud are particularly susceptible to their action. The stronger the currents, the greater is the scouring effect at the surface of the mud, and so the greater the instability of the substratum even if its texture is substantially unaltered. Where the tidal zone is broad, as in most parts of the Tamar estuary basin, the narrowing of the channel on the 
ebb tide brings an accompanying increase in the flow of the water (and a corresponding decrease towards high water on the flood). Despite the fact that the tide is flowing more slowly at the low-water period than at half-tide, when these and other relevant phenomena are taken into consideration, it is clear that the scour must be much greater near low water than in the upper half of the tidal zone. The interplay of water currents, furthermore, creates the contours of the mud-banks: deposition of silt occurs where currents are weak and removal where they are strong. The form of the mud-banks in return reacts on the currents, until an approximate equilibrium appears to be reached. The effect normally attained is that the mud-banks have a very gradual slope above, which increases slowly at first, then sharply towards low water; and the result is further to accentuate the increased scouring effect on the edge of the channel. Finally it emerges that the slope of the mud-bank may be taken as a useful guide to the relative scouring effect to which the surface is exposed.

Sections have been drawn of all the traverses in the same manner as that figured for St John's Lake in Fig. 7, and from them an approximate measure of the surface gradient at each station obtained. The decrease of the total fauna in places where the gradient is steeper than about $\mathrm{I}$ in 50 is consistent in all traverses. Some of the steepest gradients are encountered on the channel slopes in the highest traverses worked, where the instability of the ground is apparent, and the fauna may be reduced to nil. Locally almost level ground is found at low-water springs, e.g. at the edge of West Muds (Fig. I, D 2), and here the fauna is normally rich.

From such and other circumstantial evidence the suggestion is strong that the increased disturbance to which the ground is liable towards low water is an important factor in causing decline of population density in this direction. * Some species, it may be suspected, are affected more than others. Among those which will feel the influence first are small surface-living species (e.g. Hydrobia ulvae) and animals which occupy permanent burrows in the mud. It seems very significant that Cardium, Macoma, and Nephthys, which show the greatest tolerance of low-water conditions, do not occupy permanent burrows, in contrast to Nereis, Cyathura, Corophium, and Scrobicularia which do. The concentration of the latter species in the upper part of the tidal zone- a fact stressed above-may thus be explained. It can now also be understood why a species which ranges from moderate depths into the lower half of the tidal zone can come to show a maximum in that part of the tidal zone occupied, as, for example, Ampharete grubei (Fig. 8).

Another influence which might theoretically cause a decrease towards low water concerns the salinity conditions. As Milne (1938) has shown, in the Tamar Estuary there is a marked gradient from high to low water. Briefly,

* It is not overlooked that increase in water currents may have a certain beneficial effect. Balanus balanoides notably flourishes where there is strong water action (e.g. Moore, I935). Other plankton and detritus feeders-e.g. Scrobicularia plana-may quite possibly benefit from a moderate increase in current for the same reason. 
at high water the range of daily fluctuation is small, but towards low water becomes considerable. At the same time the average salinity of the water covering the ground decreases down the shore. In every respect the conditions become increasingly unfavourable down the shore for a marine species whose range into an estuary is limited by salinity (or for an estuarine species at the upper end of its range). Conversely conditions on the whole become increasingly adverse towards high water for an estuarine species at the lower end of its range. If salinity were the only, or the primary, limiting factor, certain results might be anticipated. Thus a marine species should become increasingly restricted to the upper part of its intertidal range as it approaches its upper limit in an estuary. Similarly for a species of more extensive range in estuaries, the optimum level should steadily rise. For an estuarine species with a lower limit within the estuary, the vertical zone should, in a seawards direction, tend to narrow down towards low water. Effects of such kinds might be expected to show in the distribution diagrams of at least the more abundant species. But, in fact, there are only minor indications. The restriction of Nereis diversicolor below mid-tide, and of Scoloplos armiger above mid-tide, in St John's Lake are in accordance with expectations; but otherwise there is a noteworthy absence of anticipated effects. The inference is that the limiting effects of salinity conditions are masked by some more important factor, such as, for example, the influence of water currents discussed above.

Two possible factors limiting species towards low water have thus been brought to notice. An adequate treatment of the subject will have to deal with a third-the obscure and somewhat paradoxical adverse effect of prolonged immersion, which appears sometimes to operate (cf. Chthamalus stellatus, Moore \& Kitching, 1939).

\section{SUMMARY}

The macrofauna of the intertidal mud-flats of the River Tamar have been investigated. Quantitative samples were taken by sieving the mud through a $0.8 \mathrm{~mm}$. sieve. Traverses of series of stations were worked at successive intervals up the river, and the tidal level of each station ascertained.

The characteristic species which inhabit the mud-flats are listed and the data secured regarding (I) population density, (2) up-river penetration, and (3) vertical distribution, are summarized and related to previous information on these points.

While some species are more or less uniformly distributed intertidally, others show marked zonation, with maxima in one part or another of the intertidal zone. Marine species which penetrate into the estuary tend to show the same intertidal distribution as in marine habitats. All five of the more strictly estuarine species are concentrated in the upper tidal levels.

In considering the limiting factors which cause a decrease of population at lower tidal levels, emphasis is placed on the probable importance of the increase in strength of water currents towards low water. 


\section{REFERENCES}

Alexander, W. B., Southgate, B. A. \& Bassindale, R., I932. The salinity of the water retained in the muddy foreshore of an estuary. Fourn. Mar. Biol. Assoc., Vol. xviII, pp. 297-8.

I935. Survey of the River Tees. Part II. The Estuary-chemical and biological. D.S.I.R. Water Pollution Research, Tech. Paper No. 5, H.M. Stationery Office.

Allen, E. J. \& TodD, R. A., I900. The fauna of the Salcombe Estuary. Fourn. Mar. Biol. Assoc., Vol. vi, pp. I5I-2I7.

I902. The fauna of the Exe Estuary. Fourn. Mar. Biol. Assoc., Vol. vi, pp. $295-335$.

Bassindale, R., I938. The intertidal fauna of the Mersey Estuary. Fourn. Mar. Biol. Assoc., Vol. xxiII, pp. 83-98.

Colman, J., I933. The nature of the intertidal zonation of plants and animals. Fourn. Mar. Biol. Assoc., Vol. xviII, pp. 435-74.

Crawford, G. I., I936. Additions to the Plymouth Marine Fauna (I93I) in the Crustacean orders Tanaidacea, Isopoda, and Amphipoda. Fourn. Mar. Biol. Assoc., Vol. xxI, pp. 95-106.

1937. The fauna of certain estuaries in west England and south Wales, with special reference to the Tanaidacea, Isopoda, and Amphipoda. Fourn. Mar. Biol. Assoc., Vol. xxI, pp. 647-62.

Ellis, W. G., I933. Calcium and resistance of Nereis to brackish water. Nature, Vol. cxxxII, p. 748.

FRASER, J. A., I932. Observations on the fauna and constituents of an estuarine mud in a polluted area. Fourn. Mar. Biol. Assoc., Vol. xviII, pp. 69-85.

Hartley, P. H. T., I939. The Saltash tuck-net fishery and the ecology of some estuarine fishes. Fourn. Mar. Biol. Assoc., Vol. xxiv, pp. I-68.

Hartley, P. H. T. \& Spooner, G. M., I938. The ecology of the Tamar Estuary. I. Introduction. Fourn. Mar. Biol. Assoc., Vol. xxiI, pp. $50 \mathrm{I}-8$.

Howes, N. H., 1939. The ecology of a saline lagoon in south-east Essex. Fourn. Linn. Soc., Zoology, Vol. xL, pp. 383-445.

LAMBERT, F. J., I930. Animal life in the marsh ditches of the Thames Estuary. Proc. Zool. Soc. London, I930, pp. 80I-8.

Marine Biological Association, 193i. Plymouth Marine Fauna (2nd edition).

MILNE, A., I938. The ecology of the Tamar estuary. III. Salinity and temperature conditions in the lower estuary. Fourn. Mar. Biol. Assoc., Vol. xxII, pp. 529-42.

MOoRe, H. B., I935. The biology of Balanus balanoides. IV. Relation to environmental factors. Fourn. Mar. Biol. Assoc., Vol. xx, pp. 279-307.

- 1937a. The biology of Littorina littorea. Part I. Growth of the shell and tissues, spawning, length of life, and mortality. Fourn. Mar. Biol. Assoc., Vol. xxI, pp. $72 \mathrm{I}-42$.

I937b. Marine fauna of the Isle of Man. Trans. Liverpool Biol. Soc., Vol. L, pp. I-293.

1939. The biology of Littorina littorea. Part II. Zonation in relation to other Gastropods on stony and muddy shores. Fourn. Mar. Biol. Assoc., Vol. xxiv, pp. 227-37.

Moore, H. B. \& Kitching, J. A., 1939. The biology of Chthamalus stellatus (Poli). fourn. Mar. Biol. Assoc., Vol. xxiII, pp. 52I-4I.

Nicol, E. A. T., I935. The ecology of a salt-marsh. Fourn. Mar. Biol. Assoc., Vol. xx, pp. 203-6r. 
PERCIVAL, E., I929. A report on the fauna of the estuaries of the River Tamar and the River Lynher. Fourn. Mar. Biol. Assoc., Vol. xxI, pp. 72I-42.

Purchon, R. D., I937. Studies on the biology of the Bristol Channel. II. An ecological study of the beach and dock at Portishead. Proc. Bristol Nat. Soc., Vol. III, pp. 3II-29.

REID, D. M., I930. Salinity interchange between sea-water in sand and overflowing fresh-water at low-tide. Fourn. Mar. Biol. Assoc., Vol. xvi, pp. 609-I4.

Rothschild, M., 1936. Gigantism and variation in Peringia ulvae Pennant 1777, caused by infection with larval trematodes. Fourn. Mar. Biol. Assoc., Vol. xx, pp. $537-46$.

1938. Further observations on the effect of trematode parasites on Peringia ulvae (Pennant) 1777. Novitates Zoologicae, Vol. XII, pp. 84-IO2.

RothsCHILD, A. \& RothSCHILD, M., 1939. Some observations on the growth of Peringia ulvae (Pennant) 1777 in the laboratory. Novitates Zoologicae, Vol. XLI, pp. 240-7.

SERventy, D. L., I934. The marine invertebrate fauna. In Scolt Head Island, edited by J. A. Steers, Cambridge, 1934, pp. 196-213.

Stephen, A. C., I929. Studies on the Scottish marine fauna: the fauna of the sandy and muddy areas of the tidal zone. Trans. Roy. Soc. Edinburgh, Vol. LvI, pp. 29I-306.

- I930. Studies on the Scottish marine fauna: the fauna of the sandy and muddy areas of the tidal zone, additional observations. Trans. Roy. Soc. Edinburgh, Vol. LVI, pp. 52I-35.

- I93I. Notes on the biology of certain lamellibranchs on the Scottish coast. Fourn. Mar. Biol. Assoc., Vol. xvir, pp. 277-300.

1932. Notes on the biology of some lamellibranchs in the Clyde area. Fourn. Mar. Biol. Assoc., Vol. xviII, pp. 5I-68.

ThAMDRUP, H. M., I935. Beiträge zur Oekologie der Wattenfauna auf experimenteller Grundlage. Medd. Komm. Danmarks Fisk. Havund., Kopenhagen, Bd x, Nr. 2, pp. I-I22.

Tutin, T. G., I936. New species of Zostera from Britain. Fourn. Botany, 1936, pp. 227-30.

WOHLENBERG, E., I937. Die Wattenmeer-Lebensgemeinschaften im Königshafen von Sylt. Helgoländer Wiss. Meeresunt., Bd. I, h. I, pp. I-92.

Wright, F. S., 1936. Report on the Maldon (Essex) Periwinkle fishery. Ministry of Agr. Fish., Fishery Investigations, Ser. II, Vol. xIv, No. 6, pp. I-37. 